\title{
High abundances of water-soluble dicarboxylic acids, ketocarboxylic acids and $\alpha$-dicarbonyls in the mountaintop aerosols over the North China Plain during wheat burning season
}

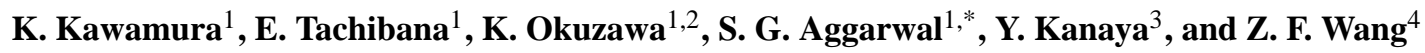 \\ ${ }^{1}$ Institute of Low Temperature Science, Hokkaido University, Sapporo, Japan \\ ${ }^{2}$ Graduate School of Environmental Science, Hokkaido University, Sapporo, Japan \\ ${ }^{3}$ Research Institute for Global Change, Japan Agency for Marine-Earth Science and Technology, Japan \\ ${ }^{4}$ LAPC, Institute of Atmospheric Physics, Chinese Academy of Sciences, China \\ *now at: CSIR, National Physical Laboratory, New Delhi, India \\ Correspondence to: K. Kawamura (kawamura@lowtem.hokudai.ac.jp)
}

Received: 30 December 2012 - Published in Atmos. Chem. Phys. Discuss.: 8 February 2013

Revised: 24 June 2013 - Accepted: 12 July 2013 - Published: 22 August 2013

\begin{abstract}
Aerosol (TSP) samples were collected at the summit of Mount Tai (elevation: $1534 \mathrm{~m}$ a.s.1., $36.25^{\circ} \mathrm{N}$, $117.10^{\circ}$ E) located in the North China Plain using a highvolume air sampler and pre-combusted quartz filters. Sampling was conducted on day/night or $3 \mathrm{~h}$ basis in the period from 29 May to 28 June 2006 during the field burning of wheat straw residue and the post-burning season. The filter samples were analyzed for low-molecular-weight dicarboxylic acids, ketoacids and $\alpha$-dicarbonyls using capillary gas chromatography (GC) and GC-MS employing water extraction and butyl ester derivatization. Molecular distributions of dicarboxylic acids $\left(\mathrm{C}_{2}-\mathrm{C}_{11}, 220-6070 \mathrm{ng} \mathrm{m}^{-3}\right)$ were characterized by a predominance of oxalic $\left(\mathrm{C}_{2}\right)$ acid $\left(105-3920 \mathrm{ng} \mathrm{m}^{-3}\right)$ followed by succinic $\left(\mathrm{C}_{4}\right)$ or malonic $\left(\mathrm{C}_{3}\right)$ acid. Unsaturated aliphatic diacids, including maleic (M), isomaleic (iM) and fumaric (F) acids, were also detected together with aromatic diacids (phthalic, isophthalic and terephthalic acids). $\omega$-oxocarboxylic acids $\left(\mathrm{C}_{2}-\mathrm{C}_{9}, 24\right.$ $610 \mathrm{ng} \mathrm{m}^{-3}$ ) were detected as the second most abundant compound class with the predominance of glyoxylic acid (11-360 $\mathrm{ng} \mathrm{m}^{-3}$ ), followed by $\alpha$-ketoacid (pyruvic acid, 3$140 \mathrm{ng} \mathrm{m}^{-3}$ ) and $\alpha$-dicarbonyls (glyoxal, $1-230 \mathrm{ng} \mathrm{m}^{-3}$ and methylglyoxal, $2-120 \mathrm{ng} \mathrm{m}^{-3}$ ). We found that these levels (>6000 $\mathrm{ng} \mathrm{m}^{-3}$ for diacids) are several times higher than those reported in Chinese megacities at ground levels. The concentrations of diacids increased from late May to early June, showing a maximum on 7 June, and then sig-
\end{abstract}

nificantly decreased during the period 8-11 June, when the wind direction shifted from southerly to northerly. Similar temporal trends were found for ketocarboxylic acids and $\alpha$ dicarbonyls as well as total carbon (TC) and water-soluble organic carbon (WSOC). The temporal variations of watersoluble organics were interpreted by the direct emission from the field burning of agricultural wastes (wheat straw) in the North China Plain and the subsequent photochemical oxidation of volatile and semi-volatile organic precursors emitted from field burning as well as dark ozonolysis of volatile organic compounds and other organics, accretion reactions and oxidation of nonvolatile organics such as unsaturated fatty acids. This study demonstrates that the field burning of agricultural wastes in early summer strongly influenced the air quality of the free troposphere over the North China Plain.

\section{Introduction}

Central East China (CEC) is one of the most polluted regions in the world due to the rapid economic growth in the last two decades (Ohara et al., 2007). Very high levels of column $\mathrm{NO}_{2}$ have been reported in the CEC region by satellite observation compared to those for the northeast of the United States and northern Europe (Richter et al., 2005). High levels of tropospheric ozone are also commonly obtained in this region based on the observations from ground sites (e.g., Gao 
et al., 2005) and satellite (e.g., Hayashida et al., 2008). Air pollution is a very serious problem in China as a result of increased usage of fossil fuels. One-fourth of primary anthropogenic organic aerosols in the world is generated in China, ca. $70 \%$ of which is derived from coal burning (Cooke et al., 1999; Streets et al., 2004). The air pollutants, in particular, dusts and anthropogenic aerosols are responsible to the degradation of visibility, health risks to human beings and climate changes in East Asia and the outflow regions including the North Pacific (Huebert et al., 2003). Recently, field burning of agricultural wastes is found to be a source of serious air pollution in East China (Fu et al., 2008; Li et al., 2008; Wang et al., 2009).

High loadings of organic aerosols have been reported in Chinese cities (Wang and Kawamura, 2005; Wang et al., 2006a), among which low-molecular-weight (LMW) dicarboxylic acids are recognized as the most abundant organic compound class (Ho et al., 2007). In general, their molecular distributions are characterized by the predominance of oxalic acid $\left(\mathrm{C}_{2}\right)$, followed by malonic $\left(\mathrm{C}_{3}\right)$ and succinic $\left(\mathrm{C}_{4}\right)$ acids. LMW dicarboxylic acids have been reported in urban (Kawamura and Ikushima, 1993; Sempéré and Kawamura, 1994; Rohrl and Lammel, 2001; Wang et al., 2002; Yao et al., 2002; Rompp et al., 2006; Kitanovski et al., 2011), mountainous (Legrand et al., 2007), marine (Kawamura and Sakaguchi, 1999; Mochida et al., 2003a, b) and Arctic and Antarctic atmospheres (Kawamura et al., 1996a, b; Kerminen et al., 1999; Narukawa et al., 2002, 2003; Kawamura et al., 2005, 2010). In general, concentrations of LMW diacids were found to be higher in Asian cities and its coastal regions in the Asian Pacific region (Fu et al., 2013).

Because small dicarboxylic acids and related polar compounds are highly water soluble and abundant in atmospheric aerosols, they can significantly enhance the hygroscopicity of the particles (Saxena et al., 1995; Saxena and Hildemann, 1996). Previous studies have shown that the presence of dicarboxylic acids affect both deliquescence relative humidity and hygroscopicity of aerosol particles (Cruz and Pandis, 1998; Brooks et al., 2002). Although LMW diacids can be emitted from primary sources such as vehicular exhausts (Kawamura and Kaplan, 1987), biomass burning (Legrand and de Angelis, 1996; Narukawa et al., 1999), cooking (Schauer et al., 2002) and natural marine sources (Rinaldi et al., 2011), they are mainly produced from the atmospheric photooxidation of various organic precursors (Kawamura and Gagosian, 1987; Stephanou, 1992; Kawamura and Sakaguchi, 1999) most likely in the aqueous aerosol phase (e.g., Sorooshian et al., 2006; Carlton et al., 2007; Ervens et al., 2008, 2011). LMW dicarboxylic acids and related compounds can contribute to $0.2-1.8 \%$ of total carbon (TC) in urban Tokyo (Kawamura and Ikushima, 1993) and up to $16 \%$ of TC in remote marine aerosols (Kawamura and Sakaguchi, 1999; Wang et al., 2006b).

In this study, we collected atmospheric aerosols at the summit of Mt. Tai, located in CEC, from late May to June in
2006 in order to characterize water-soluble organic aerosols at molecular levels during the field-burning season of agricultural waste (wheat straw) and after. The sample collection was performed as part of the Mount Tai Experiment 2006 campaign (MTX2006) in early summer. Kanaya et al. (2013) report an overview of the MTX2006 campaign with many outcomes of the project: for example, high concentrations of ozone, volatile organic compounds including glyoxal and methylglyoxal, inorganic ions, black carbon, satellite observation of tropospheric $\mathrm{NO}_{2}$, etc. Here, we report the molecular distributions of diacids, ketoacids and $\alpha$-dicarbonyls in atmospheric particles as well as total carbon (TC) and watersoluble organic carbon (WSOC). To better understand their sources, transport pathways and photochemical processing during long-range atmospheric transport, we compare the results of the mountaintop observation with those from Chinese urban sites and the outflow regions in East Asia and the Pacific Ocean. We also discuss the photochemical processing of organic aerosols in the free troposphere over the polluted regions of the North China Plain based on the detailed analyses of molecular compositions of diacids and related compounds.

\section{Samples and experiment}

\subsection{Sampling site and aerosol collection}

Mount Tai $\left(36.25^{\circ} \mathrm{N}, 117.10^{\circ} \mathrm{E}\right)$ is located in Shandong Province, central East China $\left(30^{\circ} \mathrm{N}-40^{\circ} \mathrm{N}, 110^{\circ} \mathrm{E}-130^{\circ} \mathrm{E}\right)$, whose topography is characterized by flat lands of less than $200 \mathrm{~m}$ in altitude. Thus, Mt. Tai (elevation: $1534 \mathrm{~m}$ above sea level) is an independent peak in the CEC region (see Fig. 1) and the summit often stays within the free troposphere at night. As part of the MTX2006 campaign, daytime/nighttime and $3 \mathrm{~h}$ aerosol samplings were performed from 28 May to 28 June 2006 on the balcony of two-story building of the observatory ( $\sim 10 \mathrm{~m}$ above ground level) on the top of Mt. Tai. Eighty-one samples (including 5 whole-day, 19 daytime (06:00-18:00 LT), 20 nighttime (18:00-06:00) and 37 $3 \mathrm{~h}$ samples) were collected during the campaign using a high-volume air sampler and pre-combusted $\left(450^{\circ} \mathrm{C}\right.$ for $\left.6 \mathrm{~h}\right)$ quartz fiber filters at a flow rate of $1.0 \mathrm{~m}^{3} \mathrm{~min}^{-1}$. We collected TSP samples rather than $\mathrm{PM}_{2.5}$ in order to obtain the information of bioaerosols including pollen and fungal spores whose particle sizes are larger than $\mathrm{PM}_{2.5}$ (Fu et al., 2008). Four blanks were taken during the campaign by setting the filter on the filter cartridge without sucking air. The filter sample was placed in a clean glass bottle $(150 \mathrm{ml})$ with a Teflon-lined screw cap and stored in a freezer at the observatory. After shipping to Sapporo, the samples were stored in a freezer room at $-20^{\circ} \mathrm{C}$ prior to analyses.

The heights of planetary boundary layer (PBL) around Mt. Tai were estimated during the campaign using a WRF/Chem model (Takigawa et al., unpublished data), 


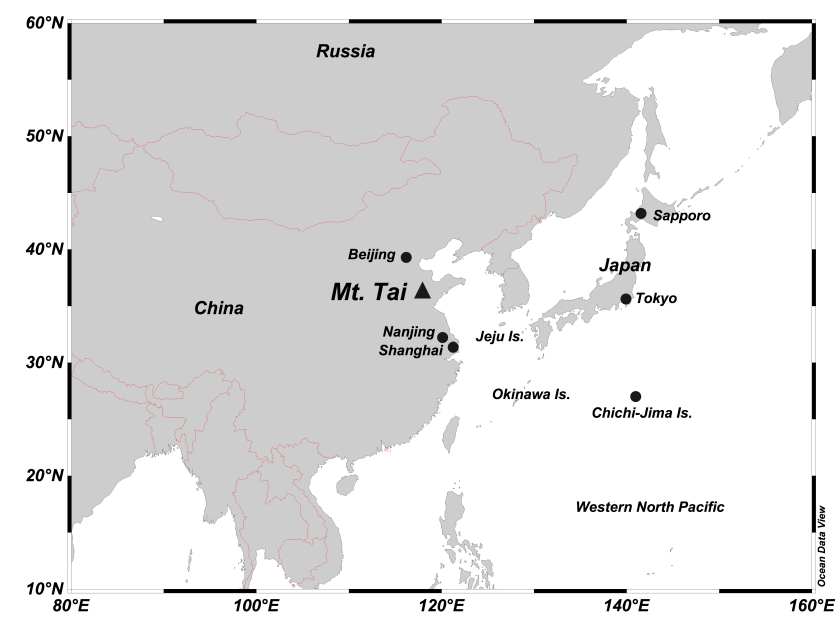

Fig. 1. A map of East Asia with the location of Mt. Tai (sampling site, triangle) and major megacities in Asia.

which reached a maximum of ca. $4000 \mathrm{~m}$ at midday and a minimum of $200 \mathrm{~m}$ during night to early morning with average heights of $2200 \mathrm{~m}$ (daytime) and $600 \mathrm{~m}$ (nighttime). Thus, nighttime samples were most likely collected in the free troposphere.

The meteorological data are obtained at the Mt. Tai observatory located on the mountaintop. The results are summarized in Fig. 2. The ambient temperatures ranged from 8 to $24^{\circ} \mathrm{C}$. Relative humidity in daytime was generally low (around $50 \%$ ) but increased over $95 \%$ at night. Wind speeds ranged from less than $1 \mathrm{~m} \mathrm{~s}^{-1}$ to $20 \mathrm{~m} \mathrm{~s}^{-1}$. Winds generally came from the west or southwest; however, the northwest to north winds dominated during the periods of 8-11 June and 14-15 June, when cold and dry air masses arrived over Mt. Tai from North China and Siberia (see Fig. 2). Weather conditions were generally clear or partly cloudy throughout the campaign, but minor rain events occurred on 7, 13, 14, 21, 26 and 28 June. A major rain event occurred on 29 June. However, the filter sampling was ended just before the large rainstorm.

\subsection{Analytical procedures}

Aliquots of filter samples were extracted with organic-free pure water (Milli-Q) to separate water-soluble diacids and related organic compounds. The water extracts were concentrated using a rotary evaporator under vacuum and then converted to dibutyl esters and butoxy acetals employing the derivatization with $14 \% \mathrm{BF}_{3}$ in $n$-butanol (Supelco). The derivatives were dissolved in $n$-hexane $(100$ or $200 \mu \mathrm{l})$ and two $\mu$ of the $n$-hexane solution were injected into a gas chromatograph (GC, Agilent 6980) installed with a split/splitless injector $\left(250^{\circ} \mathrm{C}\right)$, HP- 5 column $(0.2 \mathrm{~mm} \times 25 \mathrm{~m}$, film thickness $0.5 \mu \mathrm{m})$ and FID detector for the determination of dicarboxylic acids $\left(\mathrm{C}_{2}-\mathrm{C}_{10}\right)$, ketocarboxylic acids $\left(\mathrm{C}_{2}-\mathrm{C}_{9}\right)$ and $\alpha$-dicarbonyls (glyoxal and methylglyoxal) (Kawamura,

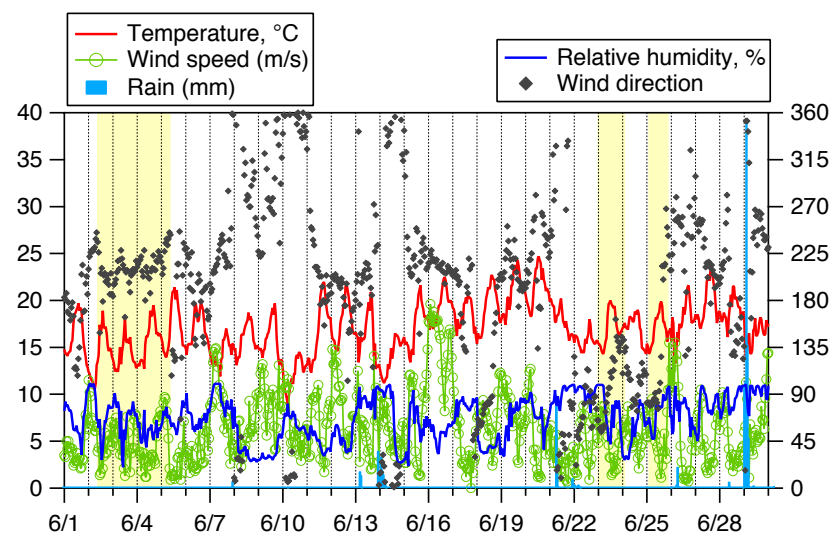

Fig. 2. Summary of meteorological data obtained at Mt. Tai Observatory in central East China. The left $y$ axis is for ambient temperature, wind speed and rainfall, whereas the right axis shows relative humidity (\%) and wind direction (degree).

1993; Kawamura and Ikushima, 1993). GC/mass spectrometer (Thermo Trace MS) was used to confirm the identification of the GC peaks (Kawamura et al., 1985; Kawamura, 1993). Quantifications of diacids and related compounds were performed by the comparison of GC-FID responses of the derivatives with those of authentic succinic acid dibutyl ester assuming that the FID responses (GC peak area) are proportional to the amounts of carbon atoms of the esters and derivatives regardless of the chemical structures. The reliability of this technique is verified using dibutyl esters of $\mathrm{C}_{2}-\mathrm{C}_{10}$ diacids.

A spike experiment using authentic standards (oxalic, malonic, succinic and adipic acids) that were added into quartz filter showed that recoveries were $77 \%$ for oxalic acid and better than $86 \%$ for other diacids. Recoveries of glyoxylic acid, pyruvic acid and methylglyoxal were $88 \%, 72 \%$ and $47 \%$, respectively (Kawamura and Yasui, 2005). Recovery of glyoxal was $91 \%$ (Kunwar and Kawamura, 2013, submitted to JGR). Field blank was analyzed by the analytical procedure used for the actual samples. Although the blanks showed small peaks of oxalic acid and phthalic acid on the GC chromatogram, their amounts were less than $5 \%$ of the actual samples. The concentrations of the compounds reported here are all corrected for the field blanks. Duplicate analyses of the sample showed that the analytical errors in the procedures were within $10 \%$ for major components.

Aerosol samples were also analyzed for total carbon (TC) and nitrogen (TN) contents. A small disc (area $3.14 \mathrm{~cm}^{2}$ ) was punched from aerosol filter samples and analyzed using an elemental analyzer (EA) (Carlo Erba, NA 1500) (Kawamura et al., 2004). The TC and TN contents are reported here after the blank correction. Analytical uncertainties (as presented by standard deviation relative to mean value) of TC and TN measurements were within $2 \%$ based on triplicate analyses of selected samples. 
For the measurements of water-soluble organic carbon (WSOC), another filter disc $\left(1.54 \mathrm{~cm}^{2}\right)$ was extracted with organic-free Milli-Q water for 15 min under ultrasonication. The water extracts were subsequently passed through a syringe filter (Millex-GV, $0.22 \mu \mathrm{m}$, Millipore), and WSOC was measured with a carbon analyzer (Shimadzu, TOC-5000A) equipped with a catalytic oxidation column/nondispersive infrared detector (Aggarwal and Kawamura, 2008). The sample was measured three times, and the average value was used. Before the sample analysis, external calibration was performed using a potassium hydrogen phthalate solution. The analytical uncertainties in the WSOC measurement were within $15 \%$ with a detection limit of $0.1 \mu \mathrm{g} \mathrm{C} \mathrm{m}{ }^{-3}$.

\section{Results and discussion}

\subsection{Variations of TC, TN and WSOC in the mountain aerosols}

Figure 3 shows temporal variations of total carbon (TC) and total nitrogen (TN) contents in the Mt. Tai aerosols as well as $\mathrm{C} / \mathrm{N}$ ratios. TC concentrations increased from late May to mid-June and then significantly decreased during the period 8-11 June, when wind direction shifted to northerly or northwesterly over Mt. Tai (see Fig. 2). The TC concentrations again increased during the period 12-13 June, when wind direction shifted to southerly. It is important to note that field burning of agricultural wastes (wheat straw) occurred in the south of Mt. Tai during the first half of sampling period (see Fig. 4a for the fire spot and air mass trajectories). As seen in Figs. $3 \mathrm{a}$ and 4 , it is clear that TC concentrations are high when air masses arriving over Mt. Tai traveled over the fire spots (see the fire spots in Fig. 4b). The field-burning activities in the CEC region maximized during the period 8-11 June (Fig. 4b), but TC concentrations were very low (Fig. 3a) because wind directions shifted to northerly and the air masses did not meet with the areas of intensive fire spots. In the second half of the campaign after mid-June, the fire activities declined although the fire regions migrated from the south to north of the sampling site following the northward shift in the harvest areas of the wheat crops (Fig. 4c, d). Following the decrease in the fire activities (Fig. 4c), TC concentrations decreased in the second half of the campaign (Fig. 3a).

Interestingly, ranges of TC concentrations $\left(3-85 \mu \mathrm{g} \mathrm{m}^{-3}\right)$ obtained for Mt. Tai aerosols are comparable to those (15$99 \mu \mathrm{g} \mathrm{m}^{-3}$ ) reported for 14 Chinese cities during winter, but higher than those $\left(6-35 \mu \mathrm{g} \mathrm{m}^{-3}\right)$ during summer (Wang et al., 2006a). High loadings in early June $\left(60-80 \mu \mathrm{g} \mathrm{m}^{-3}\right)$ are much higher than those reported in Tokyo $\left(10-44 \mu \mathrm{g} \mathrm{m}^{-3}\right.$, maximum in winter) (Kawamura and Ikushima, 1993). It is important to note that TC contents of Mt. Tai aerosols showed a good correlation $\left(r^{2}=0.63\right)$ with levoglucosan (a tracer of biomass burning, pyrolysis of cellulose) in the same (a)

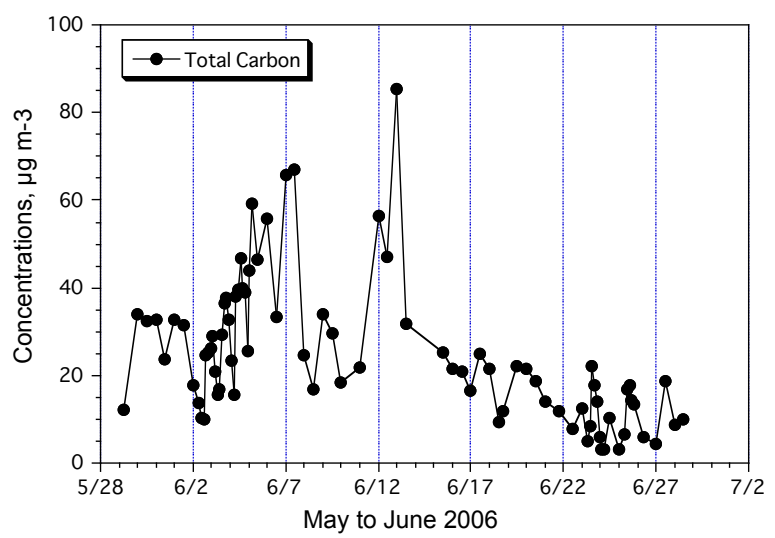

(b)

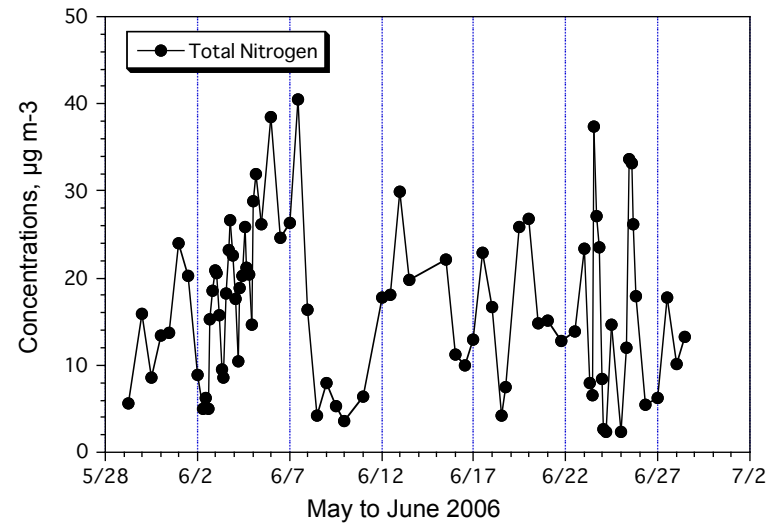

(c)

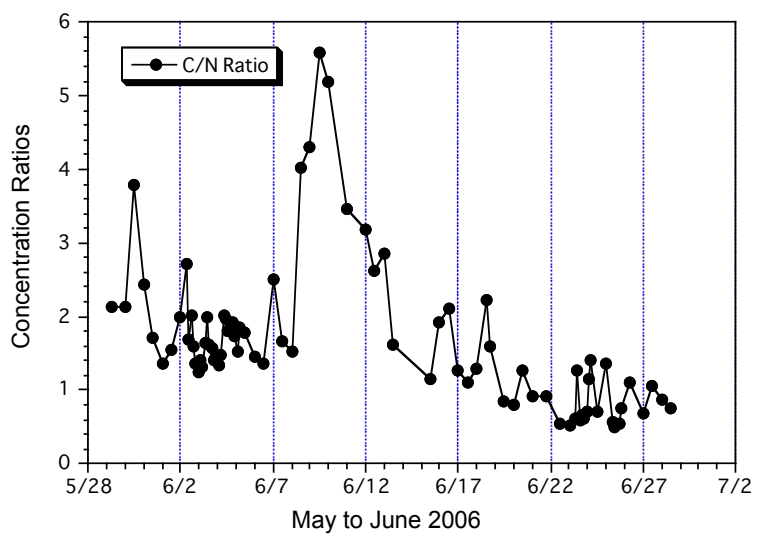

Fig. 3. Temporal variations of (a) total carbon (TC), (b) total nitrogen $(\mathrm{TN})$ and (c) $\mathrm{C} / \mathrm{N}$ concentration ratios for the atmospheric aerosols collected from Mt. Tai.

aerosol samples (Fu et al., 2008), suggesting that the peaks of TC are mainly caused by a significant contribution from field burning of agricultural wastes (wheat straw). Thus, the field burning of agricultural wastes and the atmospheric transport of burning products significantly control the TC concentrations of atmospheric aerosols over Mt. Tai. Interestingly, TC did not show a correlation with dehydroabietic acid (a tracer for burning of pines) in the Mt. Tai aerosols (Fu et al., 2008). This supports that forest fires are not the source of the Mt. Tai 
(a)

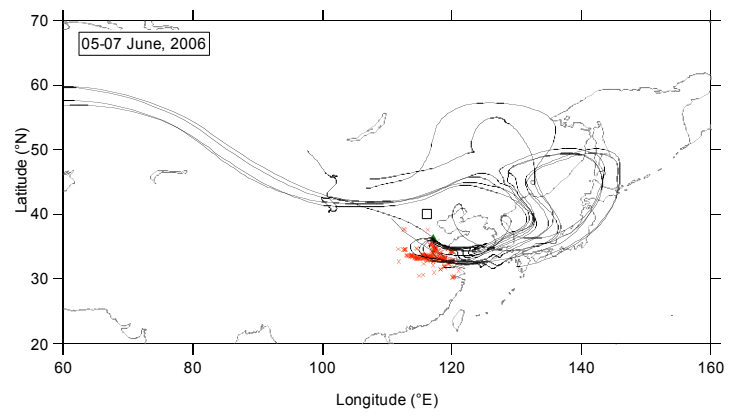

(b)

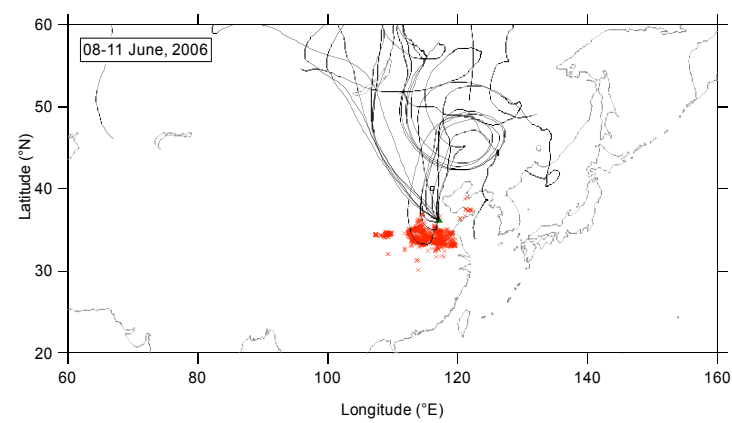

(c)

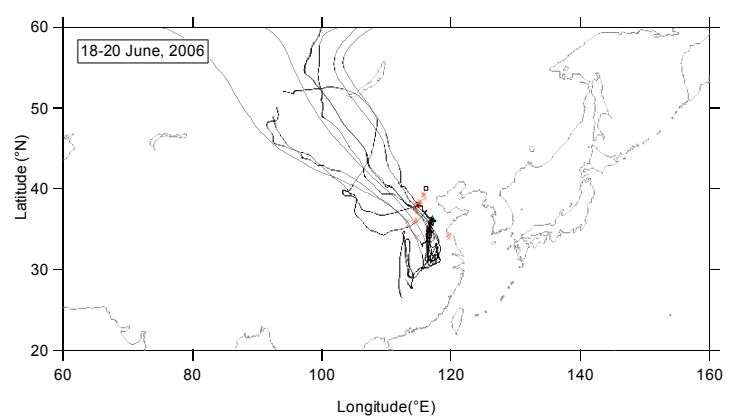

(d)

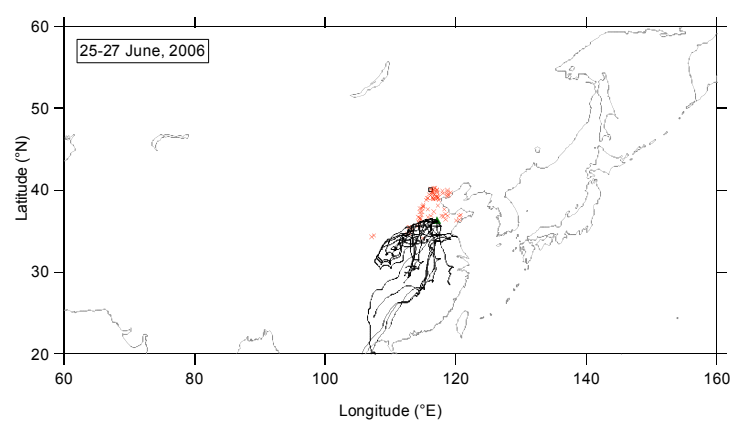

Fig. 4. Fire spots and backward air mass trajectories at Mt. Tai for selected periods in June 2006. Fire spot data were obtained from MODIS fire spot website (http://earthdata.nasa.gov/ data/near-real-time-data/firms). Air mass trajectories were drawn by the data obtained by HYSPLIT4 model from NOAA ARL Website (http://ready.arl.noaa.gov/HYSPLIT.php). The arrival height of air mass trajectory was $1500 \mathrm{~m}$ a.s.l., whereas the duration was 10 days. aerosols, but the field burning in the CEC region is the major source of the high aerosol carbon.

Day/night samples did not show a diurnal trend of TC, although $3 \mathrm{~h}$ samples collected during the periods of $2-5$, 23 and 25 June gave a peak in early morning, afternoon or evening; that is, peaks were observed at 01:27 LT (local time) on 3 June, 19:34 on 3 June, 13:38 on 4 June, 13:28 on 23 June and 13:30 on 25 June (Fig. 3a). Such a peak of TC at different time may be associated with the transport of polluted air masses together with the changes in the height of PBL over Mt. Tai, within which accumulation of biomass burning products transported upwind from the ground surface in low lands occurs. It is important to note that the two peaks appeared in the afternoon around 13:30 in late June (23 and 25 ), when the field burning of agricultural wastes declined. The daytime maxima of TC may be caused by photochemical secondary formation of organic aerosols under the lesser influence of field burning of agriculture wastes on low lands.

TN contents showed temporal variations similar to TC, except for relatively small peak for 12-13 June and relatively high peaks in late June (Fig. 3b). TN concentrations significantly declined during the period 8-11 June when winds from the north dominated over Mt. Tai and the fire spots located south of the sampling site (Fig. 4b). Clean air masses were probably transported over the sampling site during the 8-11 June period. However, when the wind direction changed to the north the TN levels again increased. Diurnal variations of $\mathrm{TN}$ were obtained during $3 \mathrm{~h}$ sampling, which showed a peak in late afternoon or evening (Fig. 3b). It is consistent with the variation of TC (Fig. 3a), although amplitudes of the TN peaks in late June are a little higher than TC (Fig. 3b). Thus, $\mathrm{C} / \mathrm{N}$ weight ratios stayed almost unchanged during the period of 31 May to 7 June (Fig. 3c). However, the ratios significantly increased up to 5.6 during the period 8-11 June, when wind direction shifted to northerly (Fig. 3c and Fig. $4 \mathrm{~b}$ ). Further, $\mathrm{C} / \mathrm{N}$ ratios decreased to the value of less than unity after 19 June, when the activity of field burning declined (Figs. $3 \mathrm{c}$ and $4 \mathrm{c}$ ). The lower $\mathrm{C} / \mathrm{N}$ ratios may be derived from the relative increases in inorganic nitrogen $\left(\mathrm{NO}_{3}^{-}\right.$and $\left.\mathrm{NH}_{4}^{+}\right)$and organic nitrogen; the latter may include amino acids and proteins.

During the period of 22-23 June, the winds came from the east or southeast (Fig. 2), suggesting that contributions of marine organic matter enriched with organic nitrogen may result in the lower $\mathrm{C} / \mathrm{N}$ ratios (Miyazaki et al., 2011). In fact, air mass trajectory analyses showed that on 23 June the trajectory hit the Yellow Sea in the southwest of the Korean Peninsula (a figure of the trajectory is not shown here). Interestingly, higher concentrations of azelaic acid were detected on 21 June (Fig. 6e). However, air mass trajectory for this date did not hit the oceanic regions, but the trajectories originated from Siberia. The source of azelaic acid may be related to terrestrial plant emissions of unsaturated fatty acids followed by photochemical oxidation during long-range atmospheric transport (Kawamura and Sakaguchi, 1999). 
(a)

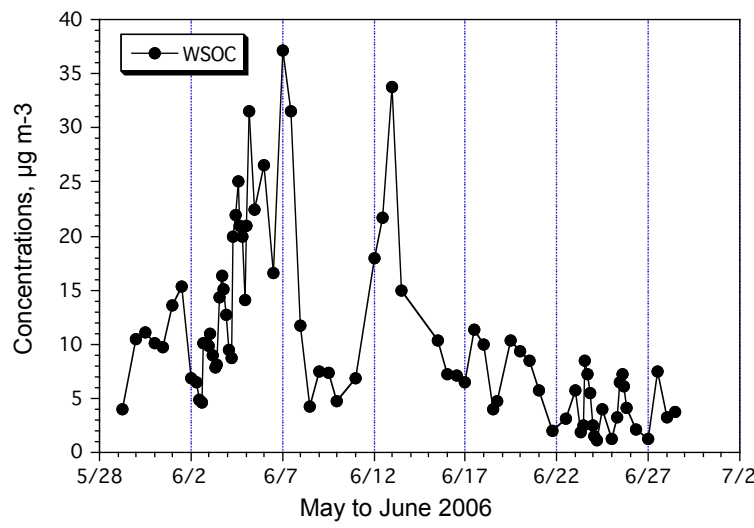

(b)

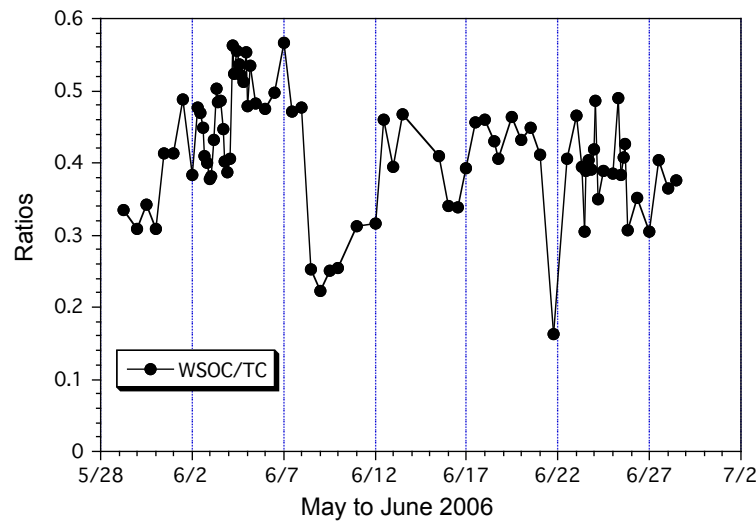

Fig. 5. Temporal variations of (a) water-soluble organic carbon (WSOC) and WSOC/TC.

Temporal variations of water-soluble organic carbon (WSOC) are shown in Fig. 5a. The WSOC variation pattern gave two peaks on 7 and 13 June, which are very similar to that of TC (Fig. 3a). However, WSOC/TC ratios are not constant (Fig. 5b). Rather, the WSOC/ TC ratios gradually increased from 0.3 in late May to 0.56 in 7 June, showing a diurnal variation with peaks early in the morning (i.e., 07:37 (center time) on 2 June, 07:38 on 3 June and 04:34 on 4 June (Fig. 5b)). The enhanced WSOC/ TC ratios may suggest aqueous phase production of WSOC in the aerosols early in the morning when relative humidity significantly increased (Fig. 2), a point to be discussed later.

Because biomass burning can produce water-soluble organic compounds such as anhydrosugars (Simoneit et al., 1999; Simoneit, 2002; Engling et al., 2006), the higher WSOC/TC ratios may be associated with more contribution of field burning to atmospheric aerosols over the agricultural fields in CEC. In fact, significant influence of biomass burning was supported by high abundances of levoglucosan (tracer of biomass burning) over Mt. Tai (Fu et al., 2008). It is also consistent with both fire spots and air mass trajectories for 5-7 June (Fig. 4a). However, the WSOC / TC ratios significantly dropped in the period 8-12 June when wind direction shifted to northerly with minimum value of 0.2 . This result indicates that the air masses delivered from the north (North China and Siberia) contain organic aerosols enriched with less water-soluble organic compounds, which may include biogenic lipid class compounds or fossil fuel combustion products. In fact, sterols, fatty alcohols and hopanes were relatively abundant in the Mt. Tai aerosols during the period of 8-10 June (Fu et al., 2008).

Diurnal variations of WSOC were observed during $3 \mathrm{~h}$ sampling periods of 2-5 June with peaks in the late afternoon or evening at 19:37 on 2 June, 16:39 on 3 June and 13:38 on 4 June (Fig. 5a). This result may suggest that more water-soluble organic compounds are transported over Mt. Tai in the late afternoon or evening by biomass burning plumes. In contrast, during the period of 23-25 June maxima of WSOC were obtained around noontime at 13:28 on 23 June and 13:30 on 25 June when the field-burning activities declined. This may suggest that photochemical oxidation of organic precursors produces more water-soluble organic species, which were probably accumulated over Mt. Tai. The latter point will be discussed in more detail using the molecular composition of dicarboxylic acids and related compounds as tracers of photochemical possessing.

\subsection{Molecular distributions of dicarboxylic acids, ketocarboxylic acids and $\alpha$-dicarbonyls}

In the Mt. Tai aerosols, we detected homologous series of $\alpha, \omega$-dicarboxylic acids $\left(\mathrm{C}_{2}-\mathrm{C}_{12}\right)$, branched-chain diacids $\left(\mathrm{iC}_{4}-\mathrm{iC}_{6}\right.$ ), unsaturated diacids (maleic, fumaric and methylmaleic), aromatic diacids (phthalic, isophthalic and terephthalic) and hydroxy diacid (malic) as well as diacids with keto-group (ketomalonic and 4-ketopimelic). Their total concentrations range from 112 to $6070 \mathrm{ng} \mathrm{m}^{-3}$. Table 1 summarizes the concentrations of dicarboxylic acids as well as ketoacids and $\alpha$-dicarbonyls with their average and median concentrations. Figure 6 presents a bar graph for these organic species in selected aerosol samples. Generally, oxalic acid $\left(\mathrm{C}_{2}\right)$ was found as the most abundant diacid species followed by malonic $\left(\mathrm{C}_{3}\right)$ and/or succinic $\left(\mathrm{C}_{4}\right)$ acids, which is consistent with previous studies of continental aerosols (Kawamura and Ikushima, 1993; Kundu et al., 2010b). However, azelaic acid $\left(\mathrm{C}_{9}\right)$ was occasionally found to be very abundant in the aerosol samples (see Fig. 6e). We also detected ketocarboxylic acids including series of $\omega$ oxocarboxylic acids $\left(\mathrm{C}_{2}-\mathrm{C}_{9}\right)$ and pyruvic acid, among which glyoxylic acid $\left(\omega \mathrm{C}_{2}\right)$ was found as most abundant ketoacid (Table 1 and Fig. 6). Such a molecular signature has been reported in previous studies of ambient aerosols (Kawamura et al., 1996a; Kawamura and Yasui, 2005; Kundu et al., 2010a, b). Two $\alpha$-dicarbonyls (glyoxal and methylglyoxal) were detected in the aerosol samples with a predominance of methylglyoxal in most samples. Concentrations of ketoacids and $\alpha$ dicarbonyls are roughly one order of magnitude lower than those of diacids (Table 1). 
Table 1. Concentrations ( $\mathrm{ng} \mathrm{m}^{-3}$ ) of dicarboxylic acids, ketocarboxylic acids and $\alpha$-dicarbonyls as well as concentrations $\left(\mu \mathrm{g} \mathrm{m}^{-3}\right)$ of TC, TN and WSOC in the aerosols collected over Mt. Tai during the period of 29 May to 28 June 2006.

\begin{tabular}{|c|c|c|c|c|}
\hline \multirow[t]{2}{*}{ Components, abbreviation } & \multicolumn{4}{|c|}{ Concentrations $\left(\mathrm{ng} \mathrm{m}^{-3}\right)$} \\
\hline & minimum & maximum & average & median \\
\hline \multicolumn{5}{|l|}{ Dicarboxylic acids } \\
\hline Oxalic, $\mathrm{C}_{2}$ & 61.0 & 3920 & 1046 & 863 \\
\hline Malonic, $\mathrm{C}_{3}$ & 7.4 & 475 & 152 & 130 \\
\hline Succinic, $\mathrm{C}_{4}$ & 7.0 & 829 & 194 & 149 \\
\hline Glutaric, $\mathrm{C}_{5}$ & 0.7 & 137 & 39.9 & 33.3 \\
\hline Adipic, $\mathrm{C}_{6}$ & 0.6 & 68.0 & 21.7 & 18.5 \\
\hline Pimelic, $\mathrm{C}_{7}$ & 0.5 & 70.1 & 18.7 & 15.3 \\
\hline Sebacic, $\mathrm{C}_{8}$ & 0.0 & 38.0 & 7.2 & 3.7 \\
\hline Azelaic, $\mathrm{C}_{9}$ & 1.8 & 313 & 31.7 & 24.1 \\
\hline Decanedioic, $\mathrm{C}_{10}$ & 0.0 & 19.5 & 3.8 & 2.9 \\
\hline Undecanedioic, $\mathrm{C}_{11}$ & 0.0 & 18.0 & 3.8 & 2.9 \\
\hline Dodecanedioc, $\mathrm{C}_{12}$ & 0.0 & 3.5 & 0.6 & 0.5 \\
\hline Methylmalonic, $\mathrm{iC}_{4}$ & 0.0 & 11.9 & 3.1 & 2.6 \\
\hline Methylsuccinic, $\mathrm{iC}_{5}$ & 1.1 & 80.8 & 17.2 & 13.1 \\
\hline 2-methylglutaric, $\mathrm{iC}_{6}$ & 0.0 & 10.3 & 3.4 & 2.6 \\
\hline Maleic, M & 0.6 & 91.0 & 12.6 & 10.4 \\
\hline Fumaric, F & 0.3 & 37.5 & 7.6 & 5.6 \\
\hline Methylmaleic, mM & 0.0 & 61.5 & 15.6 & 14.3 \\
\hline Phthalic, $\mathrm{Ph}$ & 4.8 & 131.4 & 52.0 & 45.0 \\
\hline Isophthalic, $\mathrm{iPh}$ & 0.0 & 21.4 & 6.2 & 5.2 \\
\hline Terephthalic, $\mathrm{tPh}$ & 0.6 & 112 & 22.7 & 16.3 \\
\hline Malic, $\mathrm{hC}_{4}$ & 0.0 & 43.9 & 10.2 & 6.5 \\
\hline Oxomalonic, $\mathrm{kC}_{3}$ & 3.1 & 68.0 & 19.2 & 16.2 \\
\hline 4-oxopimelic, $\mathrm{kC}_{7}$ & 0.8 & 31.6 & 13.8 & 13.3 \\
\hline Subtotal & 112 & 6073 & 1702 & 1385 \\
\hline \multicolumn{5}{|l|}{ Ketocarboxylic acids } \\
\hline Pyruvic, Pyr & 3.0 & 140 & 50.5 & 42.9 \\
\hline Glyoxylic (2-oxoethanoic), $\omega \mathrm{C}_{2}$ & 10.6 & 359 & 106 & 86.4 \\
\hline 3-oxopropanoic, $\omega \mathrm{C}_{3}$ & 2.0 & 51.9 & 19.9 & 19.5 \\
\hline 4-oxobutanoic, $\omega \mathrm{C}_{4}$ & 1.2 & 71.1 & 21.8 & 16.5 \\
\hline 5-oxopentanoic, $\omega \mathrm{C}_{5}$ & 0.3 & 16.2 & 4.4 & 3.2 \\
\hline 7-oxoheptanoic, $\omega \mathrm{C}_{7}$ & 1.1 & 42.5 & 14.3 & 12.4 \\
\hline 8-oxooctanoic, $\omega \mathrm{C}_{8}$ & 0.0 & 70.9 & 19.2 & 13.5 \\
\hline 9-oxononanoic, $\omega \mathrm{C}_{9}$ & 0.0 & 49.1 & 6.0 & 4.4 \\
\hline Subtotal & 26.6 & 742 & 242 & 210 \\
\hline \multicolumn{5}{|l|}{$\alpha$-dicarbonyls } \\
\hline Glyoxal, Gly & 1.0 & 228 & 23.1 & 17.1 \\
\hline Methylglyoxal, mGly & 1.8 & 118 & 45.2 & 42.0 \\
\hline Subtotal & 2.8 & 325 & 68.3 & 64.1 \\
\hline \multicolumn{5}{|l|}{ Bulk parameters } \\
\hline $\mathrm{TC}$ & 3.1 & 85.4 & 24.4 & 21.6 \\
\hline $\mathrm{TN}$ & 1.7 & 40.5 & 16.5 & 15.9 \\
\hline WSOC & 0.5 & 37.2 & 10.4 & 8.4 \\
\hline $\mathrm{C} / \mathrm{N}$ ratio & 0.5 & 5.6 & 1.7 & 1.5 \\
\hline
\end{tabular}

BDL: below detection limit. BDL is ca. $0.01 \mathrm{ng} \mathrm{m}^{-3}$. 
(a)

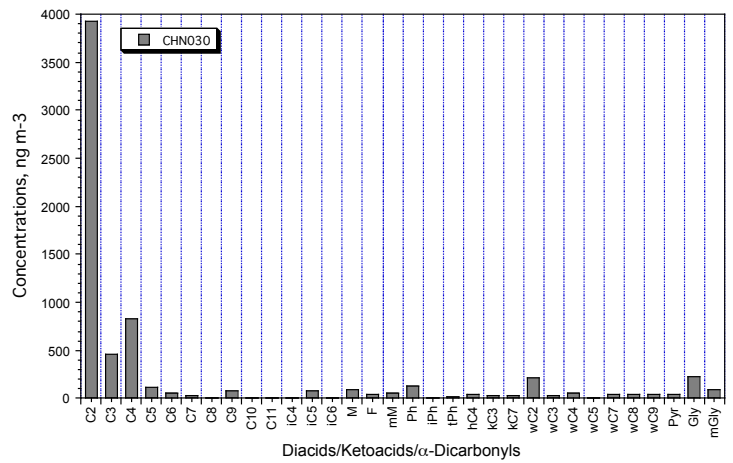

(c)

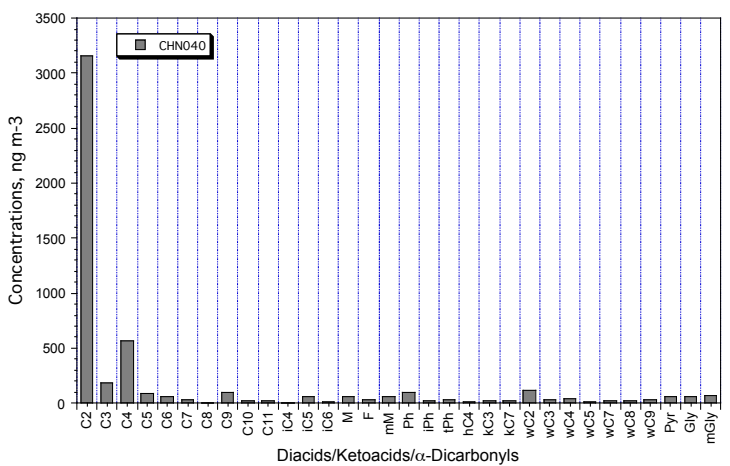

(e)

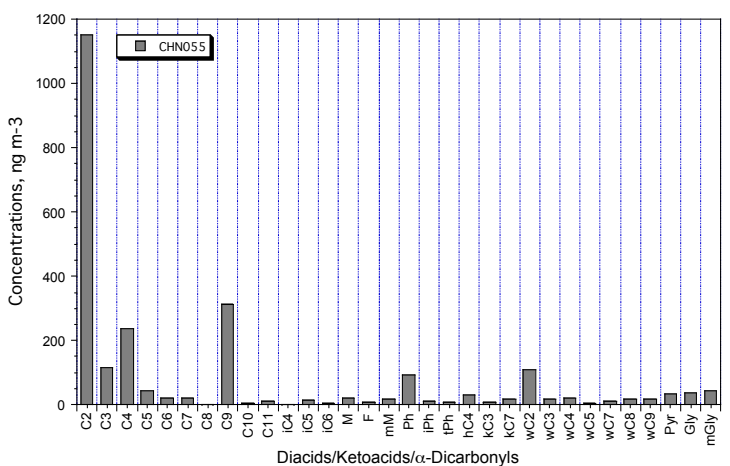

(b)

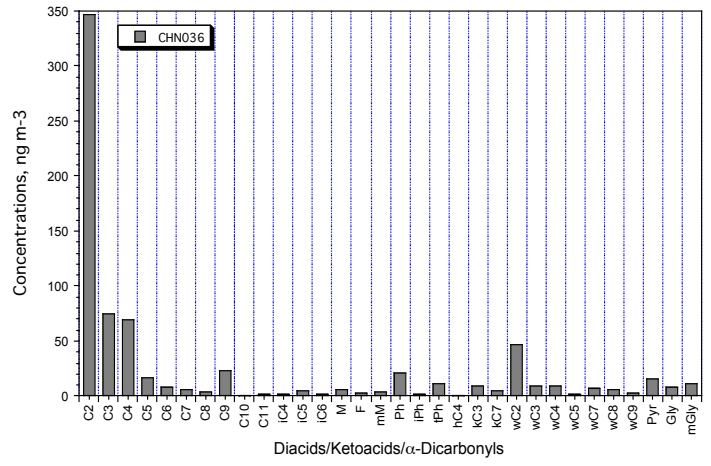

(d)

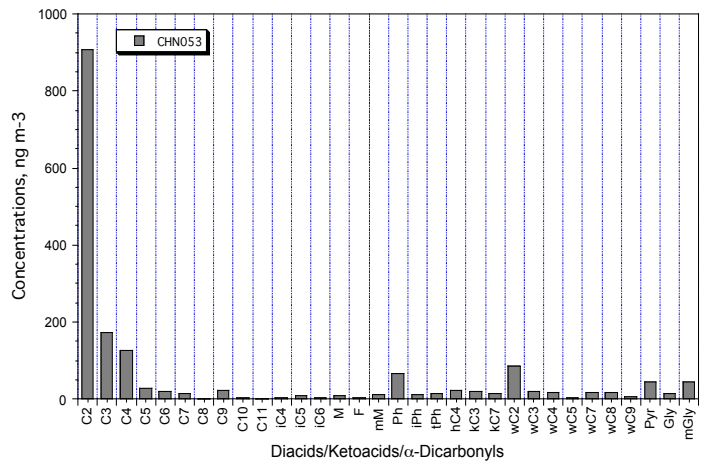

(f)

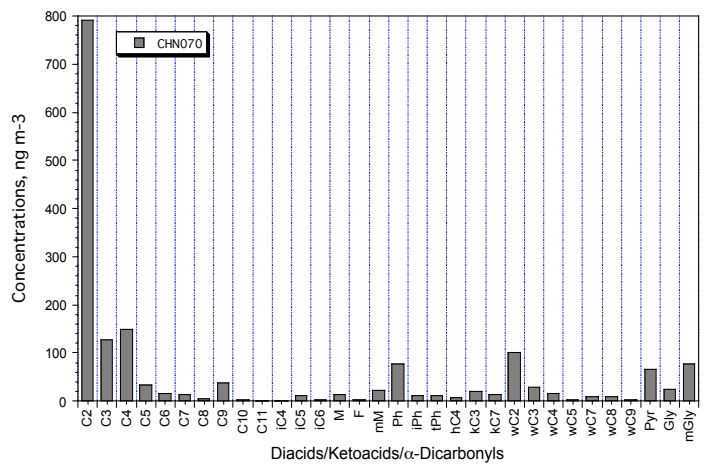

Fig. 6. Molecular distributions of dicarboxylic acids, ketocarboxylic acids and dicarbonyls detected in the selected atmospheric aerosol samples collected at the summit of Mt. Tai. (a) Sample ID: CHN030 (sampling center time and date: 00:02, 7 June), (b) CHN036 (00:01, 10 June), (c) CHN040 (0:05, 13 June), (d), CHN053 (12:01, 20 June), (e) CHN055 (18:14, 21 June) and (f) CHN070 (13:30, 25 June).

The averaged concentrations of diacids $\left(1702 \mathrm{ng} \mathrm{m}^{-3}\right)$, ketoacids $\left(242 \mathrm{ng} \mathrm{m}^{-3}\right)$ and $\alpha$-dicarbonyls $\left(68.3 \mathrm{ng} \mathrm{m}^{-3}\right)$ in the Mt. Tai aerosols (Table 1) are 2-7 times higher than those (760, 45 and $9 \mathrm{ng} \mathrm{m}^{-3}$, respectively) reported in Beijing during August/September (Ho et al., 2010) and those (660, 53 and $12 \mathrm{ng} \mathrm{m}^{-3}$, respectively) from the Gosan site, Jeju Island, outflow region of Chinese aerosols (Kundu et al., 2010b). In particular, ketoacids and $\alpha$-dicarbonyls in Mt. Tai aerosols are very high compared with megacity aerosols (Ho et al.,
2010). Further, the concentrations of Mt. Tai aerosols are 3 to 4 times higher than those $\left(438,43\right.$ and $11 \mathrm{ng} \mathrm{m}^{-3}$, respectively) reported in Pearl River Delta region near Hong Kong, South China, during winter and summer (Ho et al., 2011). Compared with European mountain sites (Legrand et al., 2007) and the High Arctic Alert station (Kawamura et al., 1996a), the concentrations of diacids in Mt. Tai aerosols are two orders of magnitude higher. These levels are significantly 
higher than those of remote marine aerosols from the Pacific (Kawamura and Sakaguchi, 1999; Miyazaki et al., 2010).

However, concentrations of diacids and related compounds in the Mt. Tai aerosols are equivalent to the levels reported in biomass burning aerosols from a pasture site in Amazonia (Kundu et al., 2010a) and in urban aerosols from New Delhi, India, in winter (Miyazaki et al., 2009). These comparisons demonstrate that the Mt. Tai aerosols are significantly enriched with diacids, ketoacids and $\alpha$-dicarbonyls, showing the highest levels in the mountaintop aerosols.

\subsection{Temporal variations of dicarboxylic acids, ketocarboxylic acids and $\alpha$-dicarbonyls and their contributions to TC and WSOC}

Figure 7a presents temporal variations of total diacids. Their concentrations increase from 2 to 7 June, quickly decrease during the 8-11 June period and then increase in 12-13 June, when the highest concentration of levoglucosan was reported (Fu et al., 2008). Interestingly, in 7 June, the concentrations of total diacids reached maximum ( $>6000 \mathrm{ng} \mathrm{m}^{-3}$ ), which is the highest value ever reported in the aerosol samples collected around the world. These variations are similar to those of TC and WSOC (Figs. 3a and 5a, respectively), again suggesting that the diacid concentrations are closely associated with the field burning of agricultural wastes and changes in the wind direction. Their concentrations also decreased toward the end of field-burning season in late June. These results suggest that diacids are largely produced as a result of biomass burning of agricultural crop wastes in the CEC region. This is supported by a positive correlation $(r=0.70)$ between total diacids (this study) and levoglucosan (Fu et al., 2008). Diacids have been reported abundantly in biomass burning plumes of the fires in Indonesia (Narukawa et al., 1999) and Amazonia (Kundu et al., 2010b).

Although we analyzed the day/night samples to discuss diurnal variations of diacids, no clear diurnal trend was detected for the diacid concentrations. However, the sample sets of $3 \mathrm{~h}$ sampling showed diurnal trends of the concentrations (Fig. 7a), although the peaking times are not consistent; that is, the diacids concentrations peaked at 01:27 on 3 June (center time of sampling), 19:34 on 3 June, 10:38 on 4 June and 04:29 on 5 June, except for the sample sets collected in the late period of the campaign, which showed a concentration peak at 13:28 on 23 June and 13:30 on 25 June (see Fig. 7a). These diurnal patterns are similar to those of TC and WSOC as described above.

Figure $7 \mathrm{~b}$ and $\mathrm{c}$ present contributions (\%) of total diacids to total carbon (TC) and water-soluble organic carbon (WSOC), respectively. Total diacid-C / TC ratios ranged from $1.2 \%$ to $6.6 \%$ with an average of $2.4 \%$. These values are much higher than those (range: 0.28 to $2.1 \%$; average: $0.87 \%$ ) reported in the marine aerosols from the Arctic Ocean in summer (Kawamura et al., 2012) and those (0.18$1.8 \%, 0.95 \%$ ) reported in urban Tokyo aerosols (Kawamura (a)

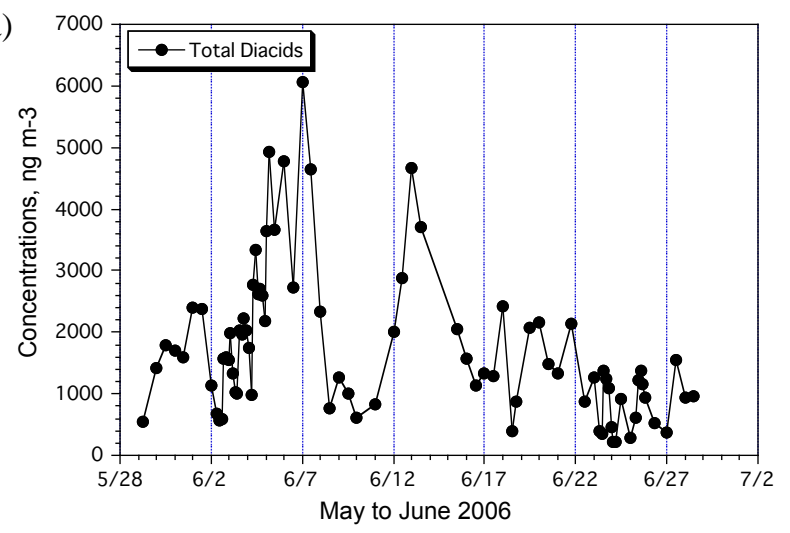

(b)

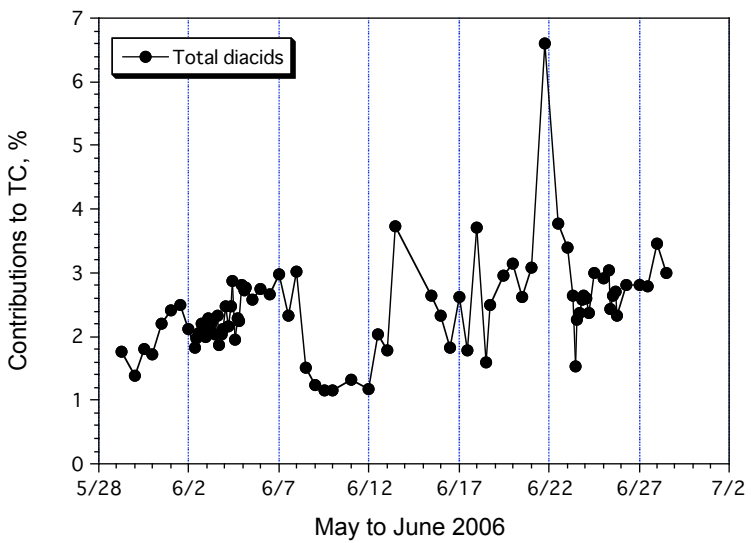

(c)

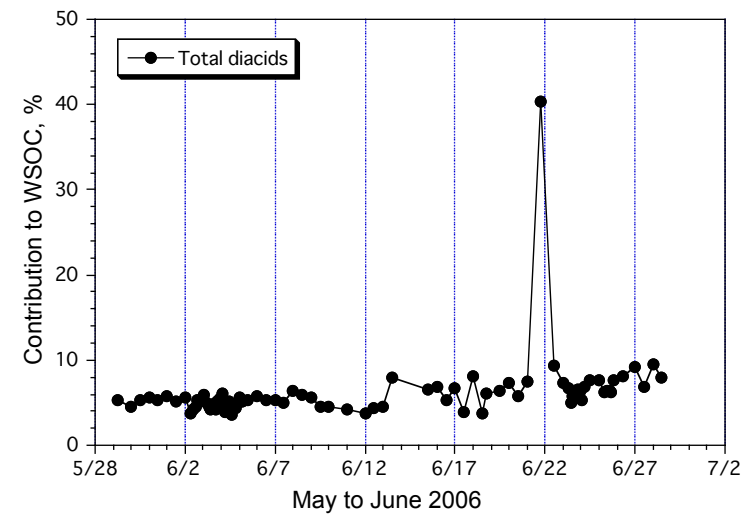

Fig. 7. Temporal variation of (a) total dicarboxylic acids $\left(\mathrm{ng} \mathrm{m}^{-3}\right)$, (b) their contributions to TC (\%), and (c) the contributions to WSOC (\%) for the aerosol samples collected at Mt. Tai.

and Ikushima, 1993). However, they are lower than those $(1.5-7.0 \%, 4.0 \%)$ reported in the Arctic (Alert) aerosols from February to June (Kawamura et al., 2010) and are significantly lower than those $(1.1-15.8 \%, 8.8 \%)$ reported in the remote marine aerosols collected in the North to central Pacific including tropics (Kawamura and Sakaguchi, 1999). Because diacid-C/TC ratios increase with photochemical aging of organic aerosols (Kawamura and Sakaguchi, 1999), 
the values obtained during the MTX2006 campaign in the North China Plain suggest that the mountaintop organic aerosols are, to some extent, processed by photochemical oxidations during atmospheric transport. However, the degree of the photochemical aging is not as strong as remote marine aerosols. We consider that the Mt. Tai aerosols are photochemically more aged than urban aerosols, but less aged than marine aerosols.

Contributions of total diacids to TC significantly dropped during the 8-11 June period, when the air mass came from the north (Fig. 7b), suggesting that the aerosols were not photochemically aged. On 22 June, a very high ratio (6.6\%) was obtained partly due to the high abundance of azelaic acid $\left(\mathrm{C}_{9}\right)$, which is a specific oxidation product of unsaturated fatty acids (Kawamura and Gagosian, 1987; Stephanou, 1992). In contrast, the contributions of total diacids to WSOC are relatively constant around at $5 \%$, although a large peak was again observed on 22 June (Fig. 7b). We did not detect any diurnal trend in the contributions of total diacids to TC and WSOC (Fig. 7b, c), suggesting no serious photochemical production of diacids over the sampling site. The diacids$\mathrm{C} / \mathrm{TC}$ or WSOC ratios may have been determined prior to the atmospheric transport over the sampling site of Mt. Tai.

Figure $8 \mathrm{a}$ shows temporal variations in the concentrations of ketocarboxylic acids in the Mt. Tai aerosols. Total ketoacids showed the variation pattern similar to diacids (Fig. 7a), although the peak on 7 June is relatively small compared to diacids. We could not detect a systematic trend for the ketoacids concentrations between day and night samples. In contrast, the time-resolved samples collected each $3 \mathrm{~h}$ showed diurnal distributions (see Fig. 8a); however, we observed that the peaks appeared differently: total ketoacids peaked at 01:27 (center time) on 3 June, 22:28 on 3 June, 10:38 on 4 June, 04:29 on 5 June, 13:28 on 23 June and 13:30 on 25 June. These peak timings are similar to those of diacids. The variability of the concentration maxima may be caused by the complicated transport processes of polluted air masses over the mountaintop, coupled with the vertical movement of the PBL during the field-burning season. However, the last two peaks appeared in the early afternoon during late June, when the field burning was weakened.

Figure $8 \mathrm{~b}$ and $\mathrm{c}$ present contributions of total ketoacids to TC and WSOC, respectively. Contributions of ketoacids to TC ranged from 0.17 to 0.81 (av. $0.43 \%$ ), whereas those to WSOC ranged from 0.4 to $4.9 \%$ (av. $1.1 \%$ ). These values (ketoacids-C/TC) are similar to those $(0.2-0.6 \%)$ reported for the Arctic aerosols from Alert (Kawamura et al., 2010), but much higher than those (0.05-0.26\%, av. $0.10 \%)$ reported for in the Arctic Ocean aerosols (Kawamura et al., 2012). This may suggest that these ketoacids are derived from biomass burning and anthropogenic sources. The ketoacids-C/TC ratios increased from 2 to 5 June, showing some diurnal peaks, and then declined toward 8-11 June, when the wind direction changed from southerly to northerly (Fig. 2). This trend is somewhat similar to that of diacids;
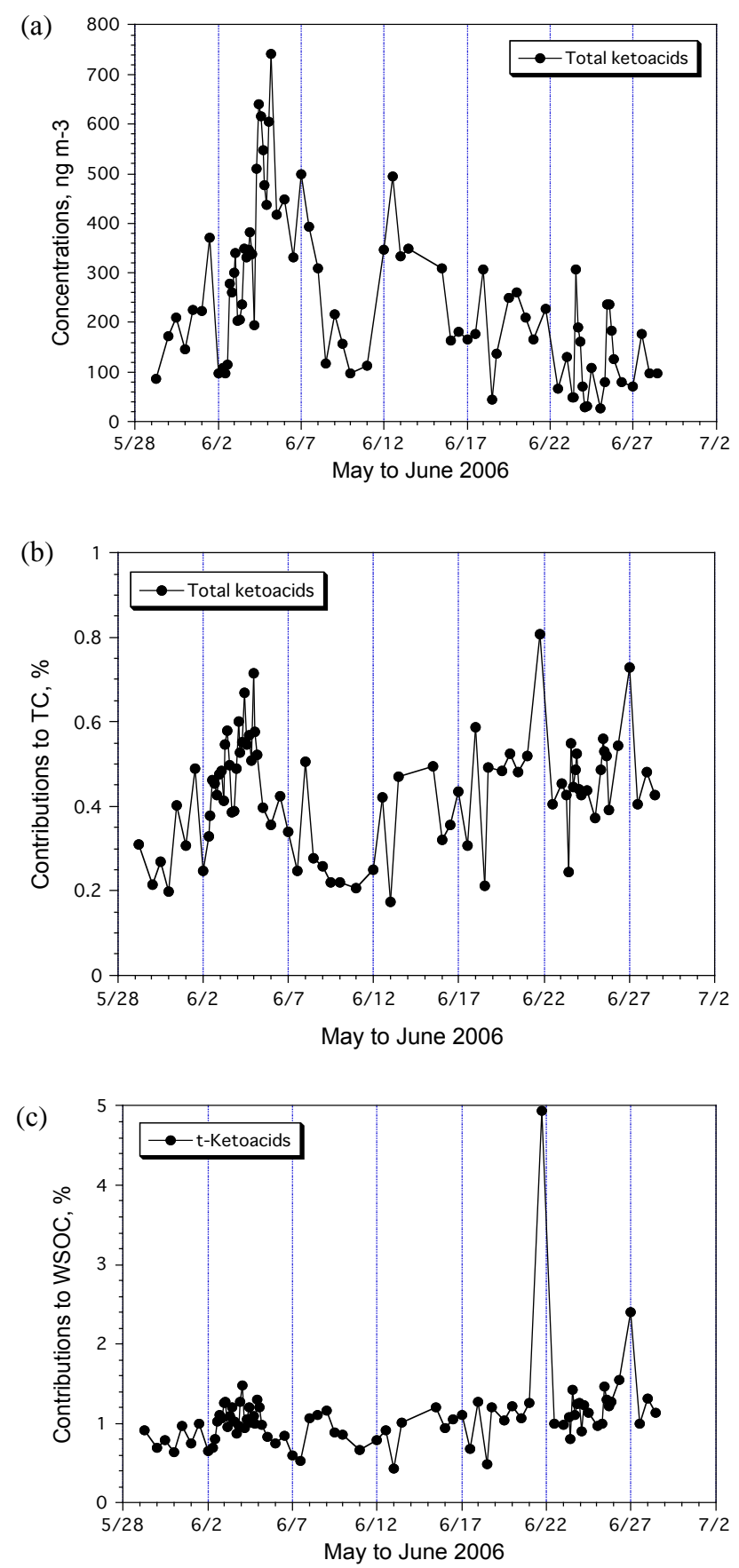

Fig. 8. Temporal variation of (a) total ketocarboxylic acids $\left(\mathrm{ng} \mathrm{m}^{-3}\right)$, (b) their contributions to TC (\%) and (c) the contributions to WSOC (\%) for the aerosol samples collected at Mt. Tai.

however, the amplitude of the drop in the 8-11 June period is not as strong as diacids (Fig. 7b). This may suggest that ketoacids (semi-volatile species) may be more partitioned to aerosol phase due to the lower ambient temperature during the period 8-11 June (Fig. 2), causing the ketoacids$\mathrm{C} / \mathrm{TC}$ ratios to be relatively high. This trend seems much clearer for the temporal variation of ketoacids-C/WSOC 
(a)

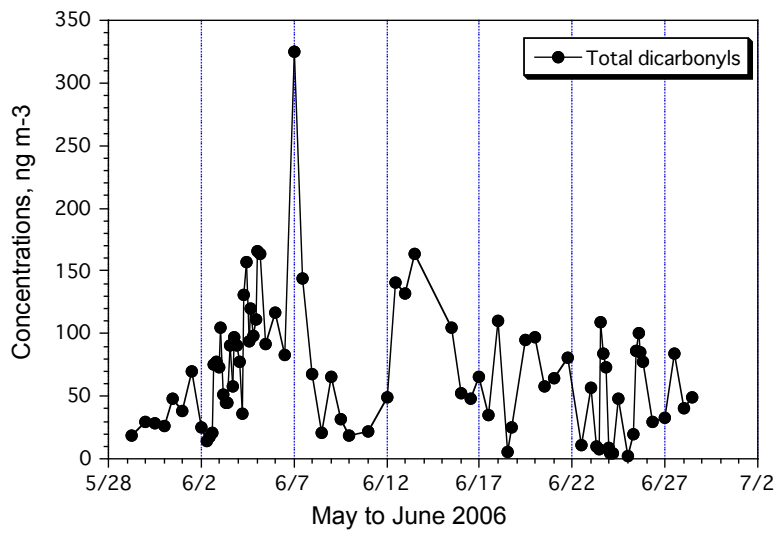

(b)

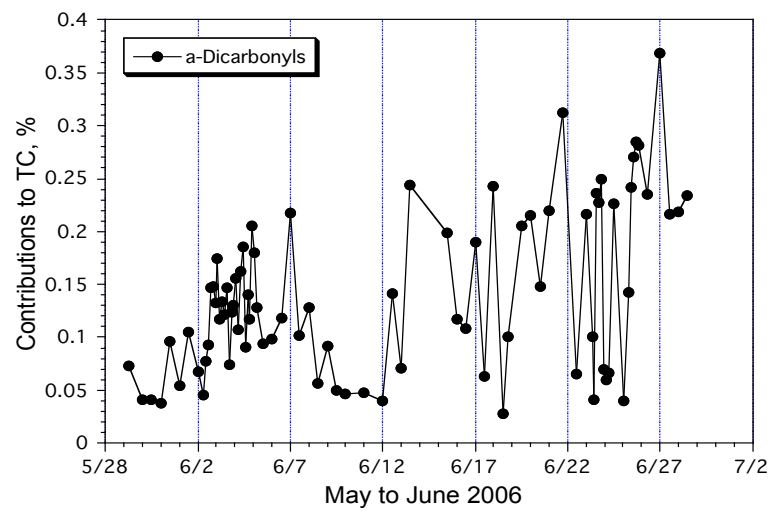

(c)

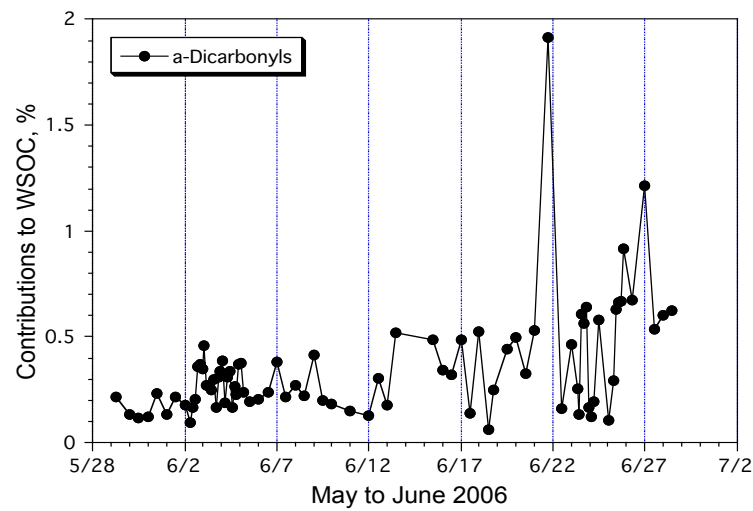

Fig. 9. Temporal variation of (a) total $\alpha$-dicarbonyls $\left(\mathrm{ng} \mathrm{m}^{-3}\right.$ ), (b) their contributions to TC (\%) and (c) the contributions to WSOC (\%) for the aerosol samples collected at Mt. Tai.

ratios (Fig. 8c), which show more constant values around $1 \%$, except for high values on 21 June.

As shown in Fig. 9a, total $\alpha$-dicarbonyls showed similar temporal variation with ketoacids, although the peak on 7 June is very large, mainly due to the high abundance of glyoxal $\left(228 \mathrm{ng} \mathrm{m}^{-3}\right)$. Diurnal variations of $\alpha$-dicarbonyls were not clearly observed in the day/night samples, being similar to ketoacids. However, diurnal variations were obtained for $3 \mathrm{~h}$ samples with concentration peaks at 01:27 on 3 June, 19:34 on 3 June, 10:38 on 4 June, 01:31 on 5 June, 13:28 on 23 June and 13:30 on 25 June (Fig. 9a). These diurnal patterns are similar to those of diacids and ketoacids. Again the last two peaks of $\alpha$-dicarbonyls appeared early in the afternoon when the field burning was weakened.

The relative abundance of $\alpha$-dicarbonyls in TC and WSOC ranged from $0.03-0.37 \%$ (av. $0.14 \%$ ) and $0.06-1.9 \%$ (av. $0.35 \%)$, respectively (Fig. 9b and c). These values ( $\alpha$ dicarbonyl-C/TC) are similar to those $(0.05-0.26 \%$, av. $0.10 \%$ ) reported for the Arctic Ocean aerosols (Kawamura et al., 2012), but bit lower than those $(0.2-0.6 \%)$ reported in the Arctic Alert aerosols (Kawamura et al., 2010). The $\alpha$-dicarbonyl-C/WSOC ratios of the Mt. Tai samples are higher than those $(0.02-0.35 \%)$ reported in the Arctic Alert aerosols that were collected in late winter to early summer including the season of polar sunrise (Kawamura et al., 2010). This result may suggest that Mt. Tai aerosols are more contributed from anthropogenic sources than the Arctic aerosols and/or be more processed by photochemical reactions. Interestingly, $\alpha$-dicarbonyls showed a positive relation with levoglucosan (biomass burning tracer) in the Mt. Tai aerosols $(r=0.54)$ (figure not shown here). Gaseous glyoxal and methylglyoxal, which are much more abundant than the aerosol phase $\alpha$-dicarbonyls, also showed a positive correlation with levoglucosan $(r=0.82$ and 0.78 , respectively) during the same campaign (Kawamura et al., 2013).

\subsection{Compositional changes of dicarboxylic acids}

Molecular compositions of dicarboxylic acids have been used as tracers of source strength (biogenic vs. anthropogenic) or photochemical processing of organic aerosols (Kawamura et al., 2012). For example, adipic $\left(\mathrm{C}_{6}\right) /$ azelaic $\left(\mathrm{C}_{9}\right)$ acid ratios and phthalic $(\mathrm{Ph}) / \mathrm{C}_{9}$ acid ratios are useful tracers to evaluate anthropogenic vs. biogenic contributions to organic aerosols because $\mathrm{C}_{6}$ and $\mathrm{Ph}$ are produced by the oxidation of anthropogenic cyclic hexene (Hatakeyama et al., 1985) and aromatic hydrocarbons such as naphthalene (Kawamura and Ikushima, 1993), whereas $C_{9}$ is produced by the photooxidation of biogenic unsaturated fatty acids that have a double bond predominantly at C-9 position (Yokouchi and Ambe, 1986; Kawamura and Gagosian, 1987; Kawamura et al., 2005). As shown in Fig. 10a and b, $\mathrm{C}_{6} / \mathrm{C}_{9}$ and $\mathrm{Ph} / \mathrm{C}_{9}$ ratios are higher in early June, when the influence of field burning is significant, suggesting more contribution from anthropogenic sources.

Biomass burning may be technically defined as anthropogenic activity (at least this is the case for $90 \%$ of all fires on a global basis), although the materials are mostly of biogenic origin. Hence, azelaic acid could be produced by the biomass burning because the biomass should contain its precursors (unsaturated fatty acids). Similarly, during the biomass burning, cyclic olefins may also be produced in a similar manner as in fossil fuel combustion processes and 
(a)

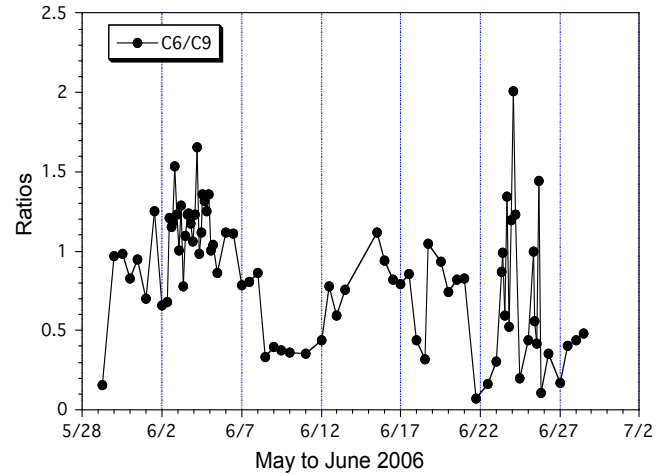

(c)

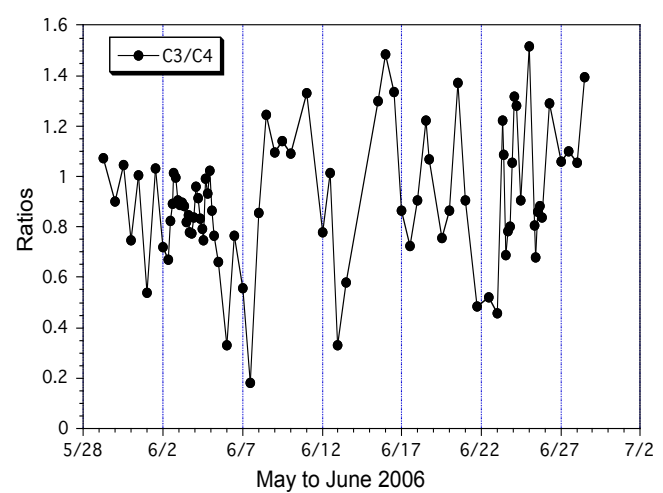

(b)

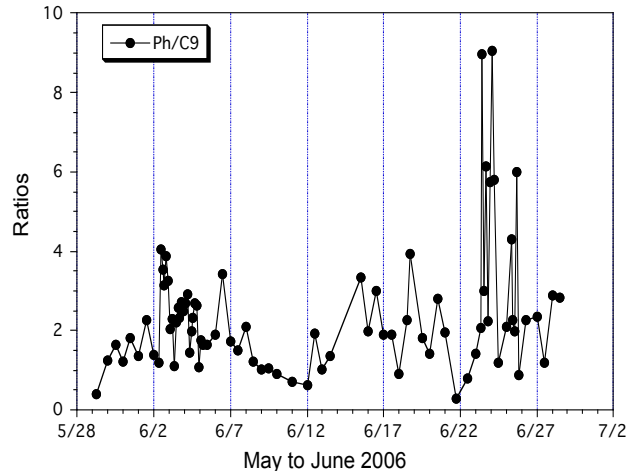

(d)

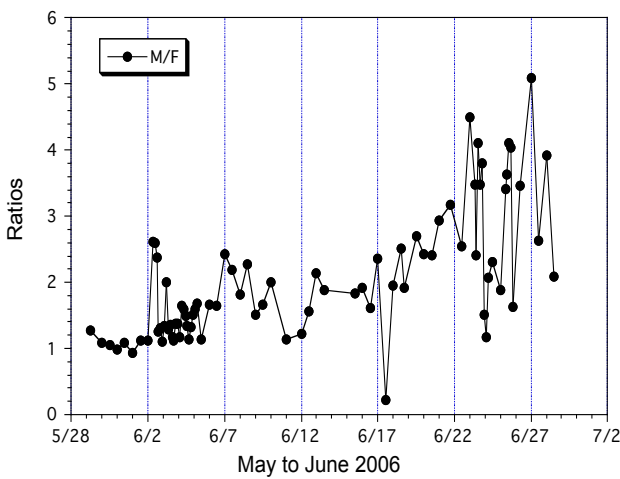

(e)

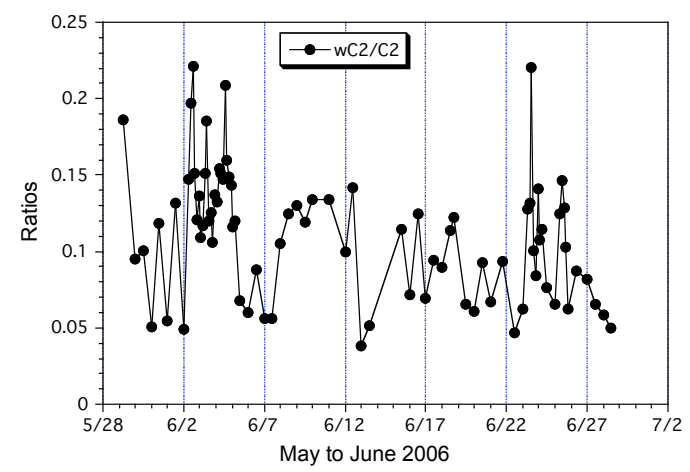

Fig. 10. Changes in concentrations ratios of (a) adipic $\left(\mathrm{C}_{6}\right) /$ azelaic $\left(\mathrm{C}_{9}\right)$ acid ratios, $(\mathbf{b})$ phthalic $(\mathrm{Ph}) / \mathrm{C}_{9}$ acid ratios, (c) malonic $\left(\mathrm{C}_{3}\right)$ /succinic $\left(\mathrm{C}_{4}\right)$ acid ratios, $(\mathbf{d})$ maleic $(\mathrm{M}) /$ fumalic $(\mathrm{F})$ acid ratios and $(\mathbf{e})$ glyoxylic $\left(\omega \mathrm{C}_{2}\right)$ / oxalic $\left(\mathrm{C}_{2}\right)$ acid ratios in the Mt. Tai aerosols.

further oxidized to $\mathrm{C}_{6}$ in the atmosphere during the transport from the ground surface to the summit of Mt. Tai. Although these possible pathways may cause a slightly complicated situations of $\mathrm{C}_{6} / \mathrm{C}_{9}$ ratios as a tracer, we feel that contributions of $\mathrm{C}_{6}$ and $\mathrm{Ph}$ from biomass burning are minimal, and thus consider that anthropogenic components of fossil combustion origin are likely transported to the mountaintop together with biomass burning plumes during the field- burning season in the North China Plain. $\mathrm{C}_{6} / \mathrm{C}_{9}$ ratios are also high in the periods of 15-16 and 19-20 June as well as $23-25$ June. In contrast, these ratios are significantly low during periods $8-11$ and 21 June, when the air masses came from North China and Siberia (Figs. 2 and 4b), suggesting that the aerosols are more influenced by biogenic sources. $\mathrm{The} \mathrm{Ph} / \mathrm{C}_{9}$ ratios of the Mt. Tai aerosols are similar to those reported for summer aerosols from Gosan site, Jeju Island 
(Kundu et al., 2010b), except for very high values (up to 9) in the period 23-25 June, which are similar to those reported from the Gosan site in winter (Kundu et al., 2010b).

Malonic $\left(\mathrm{C}_{3}\right)$ / succinic $\left(\mathrm{C}_{4}\right)$ acid ratios can be used as a tracer to evaluate the photochemical processing of organic aerosols because the $\mathrm{C}_{3} / \mathrm{C}_{4}$ ratios significantly increased up to 3 in summer following the increase of ozone in the urban Tokyo atmosphere (Kawamura and Ikushima, 1993). The ratios are low in the fossil fuel combustion products due to the thermally unstable structure of malonic acid. Figure 10c shows temporal variation of $\mathrm{C}_{3} / \mathrm{C}_{4}$ ratios in the Mt. Tai aerosols. During the first week of June, the period with an influence of field burning, the $\mathrm{C}_{3} / \mathrm{C}_{4}$ ratios were around $0.8-1.0$, and decreased down to 0.2 in 7 June, when total diacids maximized (Fig. 7a). The $\mathrm{C}_{3} / \mathrm{C}_{4}$ ratios increased during the period 8-11 June when the air masses came from the north. The higher ratios may be caused by photochemical production of $\mathrm{C}_{3}$ from $\mathrm{C}_{4}$ during a long-range atmospheric transport. The $\mathrm{C}_{3} / \mathrm{C}_{4}$ ratios declined around 13 June when diacids increased (Fig. 7a) due to the influence of field burning of wheat straw wastes. The ratios fluctuated with a peak in 15-16 June (winds came from the north) and a drop in 21-23 June (winds came from the south). The fluctuations of $\mathrm{C}_{3} / \mathrm{C}_{4}$ ratios seem to be consistent with the patterns of air mass origin and long-range transport. However, $\mathrm{C}_{3} / \mathrm{C}_{4}$ ratios $(0.2-1.5)$ are much lower than those (up to 10) from remote marine aerosols, where photochemical transformation is serious (Kawamura and Sakaguchi, 1999).

We detected unsaturated dicarboxylic acids (i.e., maleic (M) and fumaric (F) acids). Maleic acid (cis configuration) is produced by the oxidation of aromatic hydrocarbons such as toluene and benzene via combustion and/or photochemical processes and can be photo-isomerized to its trans isomer $(\mathrm{F})$. The $\mathrm{M} / \mathrm{F}$ ratios $(0.22-5.1$, av. 2.0$)$ in the Mt. Tai aerosols were found to be $>1$ except for one sample (7 June) (Fig. 10d), which is much higher than those $(0.06-1.3$, av. 0.26$)$ from the marine aerosols from the North Pacific (Kawamura and Sakaguchi, 1999). This comparison suggests that photochemical transformation is not as significant in the Mt. Tai aerosols as in marine aerosols. It is of interest to note that M/F ratios of Mt. Tai aerosols are similar to those (0.9-4) from urban Tokyo aerosols (Kawamura and Ikushima, 1993). Interestingly, $\mathrm{M} / \mathrm{F}$ ratios increased in the second half of the campaign (Fig. 10d). The higher ratios suggest that the aerosols of Mt. Tai were not seriously subjected to photochemical processing; rather they are derived from fresh aerosols either from fossil fuel combustion or biomass burning.

Glyoxylic acid $\left(\omega \mathrm{C}_{2}\right)$ is an intermediate compound to produce oxalic acid $\left(\mathrm{C}_{2}\right)$ (Kawamura et al., 1996a; Warneck, 2003; Lim et al., 2005; Hegde and Kawamura, 2012; Wang et al., 2012). Thus, $\omega C_{2} / C_{2}$ ratios can serve as a tracer to evaluate the oxidation process of organic aerosols. Figure 10e presents the temporal variation of $\omega \mathrm{C}_{2} / \mathrm{C}_{2}$ ratios in the Mt. Tai aerosols. Although the ratios varied signif- icantly with the range of 0.04 to 2.2 , we found that during $3 \mathrm{~h}$ sampling periods the $\omega \mathrm{C}_{2} / \mathrm{C}_{2}$ ratios maximized in late morning (center time around 10:30) or early afternoon (around 13:30) and minimized in late evening or night. The maxima of the ratios in daytime probably suggest that glyoxylic acid is preferentially formed by photochemical oxidations of various precursors, including anthropogenic volatile organic compounds (VOC) as well as biogenic VOC such as isoprene during daytime, when solar radiation and oxidants (e.g., ozone) are enhanced (Kanaya et al., 2013). These observations are consistent with the diurnal distributions of glyoxylic acid in the time-resolved aerosols from Tokyo, whose concentrations showed a positive correlation with ambient temperature and ozone (Kawamura and Yasui, 2005). In the late afternoon or night to early morning, when relative humidity increases, $\omega \mathrm{C}_{2}$ can be oxidized to oxalic acid possibly in the aerosol aqueous phase (Warneck, 2003; Miyazaki et al., 2009; He and Kawamura, 2010).

\subsection{Photochemical processing of diacids and related compounds as a function of relative abundance of oxalic acid}

Relative abundance of oxalic acid $\left(\mathrm{C}_{2} \%\right)$ in total normal saturated diacids $\left(\mathrm{C}_{2}-\mathrm{C}_{10}\right)$ has been proposed as a tracer to evaluate the photochemical aging of organic aerosols because $\mathrm{C}_{2}$ is produced by the oxidation of longer-chain diacids and other precursor compounds (Kawamura and Sakaguchi, 1999). Laboratory experiments also showed that $C_{2}$ is produced by the oxidation of longer-chain diacids such as $\mathrm{C}_{3}$, $\mathrm{C}_{4}$ and $\mathrm{C}_{6}$ (Charbouillot et al., 2012). Figure 11a-d provide relative abundances of $\mathrm{C}_{2}$ and its precursors (e.g., pyruvic acid methylglyoxal) in TC or WSOC as a function of $\mathrm{C}_{2} \%$. Relative contributions of $\mathrm{C}_{2}$ to TC increased with an increase in $\mathrm{C}_{2} \%$ (Fig. 11a). A similar result was obtained for the contribution of $\mathrm{C}_{2}$ to WSOC (Fig. 11b). These results support that oxalic acid is more produced during the photochemical aging of organic aerosols. Interestingly, we found that $\mathrm{C}_{2} / \mathrm{C}_{4}$ ratios increased with an increase in $\mathrm{C} 2 \%$ (correlation coefficient $r=0.83$; figure is not shown here). We also confirmed that $\mathrm{C}_{3}-\mathrm{C}_{10}$ diacid-C / TC ratios inversely correlate with $\mathrm{C}_{2} \%$ (figure is not shown here), supporting that longer-chain diacids serve as precursors of oxalic acid in the mountaintop aerosols over the North China Plain. Intermediate compounds (e.g., pyruvic acid and methylglyoxal) that can serve as precursor of oxalic acid also show an increase relative to TC as a function of $\mathrm{C}_{2} \%$ (Fig. 11c and d), although the plots for pyruvic acid and methylglyoxal are somehow scattered (Fig. 11c, d). This may suggest that the oxidation of the intermediates to oxalic acid is slower than their replenishment in the atmosphere. These results again suggest that in addition to the formation of end product (i.e., oxalic acid), intermediate precursors are also produced in the atmosphere during the photochemical aging of organic aerosols. 
(a)

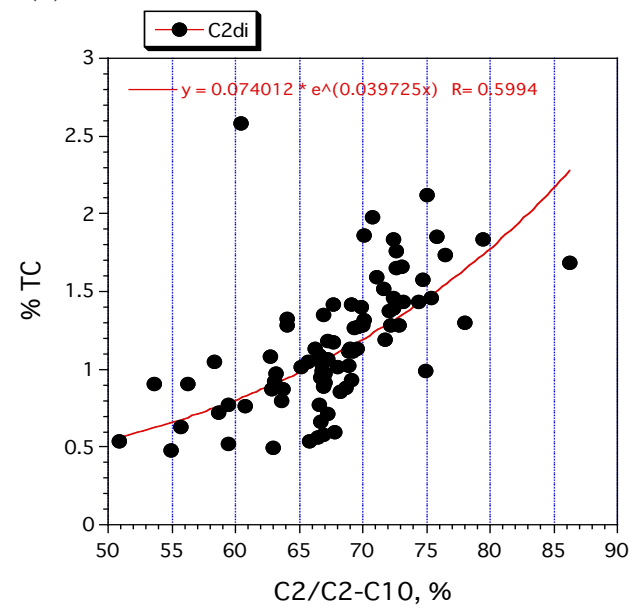

(c)

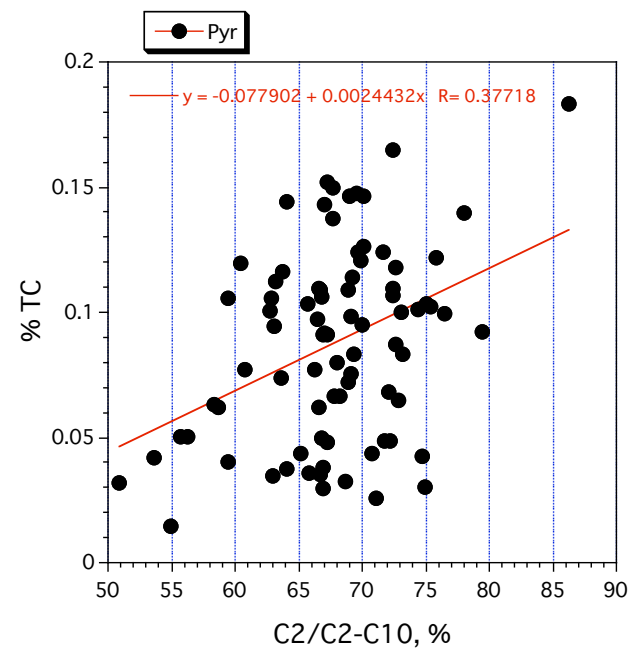

(e)

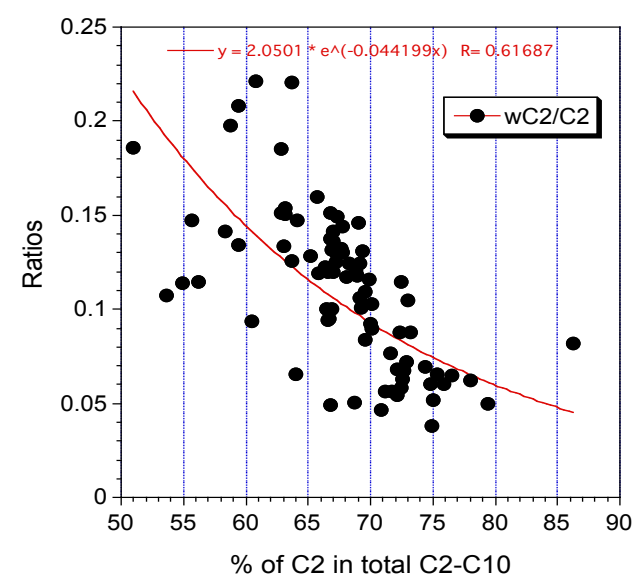

(b)

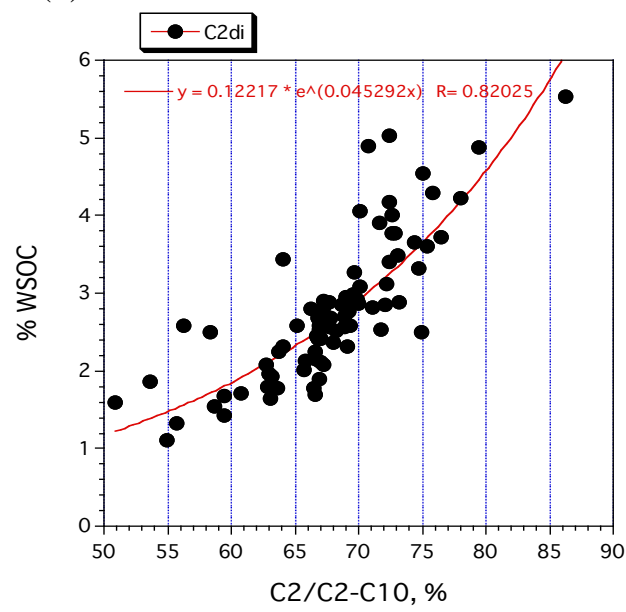

(d)

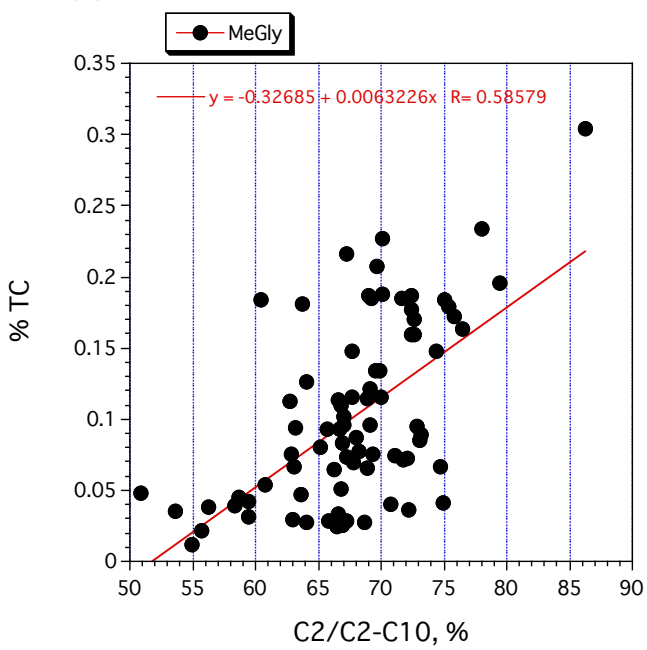

(f)

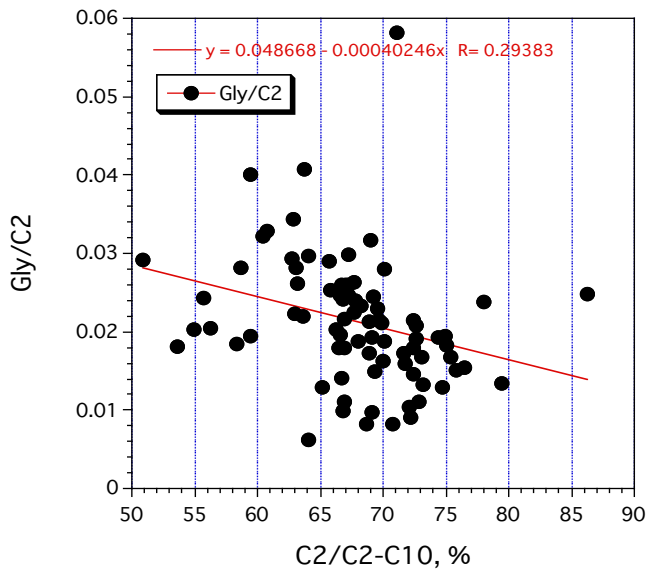

Fig. 11. Changes of contributions of (a) oxalic acid $\left(\mathrm{C}_{2}\right)$ to total carbon (TC), (b) $\mathrm{C}_{2}$ to water-soluble organic carbon (WSOC), (c) pyruvic acid (Pyr) to TC, and (d) methylglyoxal (mGly) to TC, and of (e) glyoxylic acid $\left(\omega \mathrm{C}_{2}\right) /$ oxalic $\left(\mathrm{C}_{2}\right)$ acid ratios and (f) glyoxal $(\mathrm{Gly}) / \mathrm{C}_{2}$ ratios as a function of relative abundance of $\mathrm{C}_{2}$ in $\mathrm{C}_{2}-\mathrm{C}_{10}$ diacids in the Mt. Tai aerosols. 
To understand the relations between the intermediate precursor (e.g., glyoxylic acid) and end product (i.e., oxalic acid), correlation plots were drawn between the precursor/product concentration ratios and $\mathrm{C}_{2} \%$. We found a negative correlation between $\omega \mathrm{C}_{2} / \mathrm{C}_{2}$ ratio and $\mathrm{C}_{2} \%$ (Fig. 11e). Similar negative relation was obtained for $\omega \mathrm{C}_{2} / \mathrm{TC}$ ratios and $\mathrm{C}_{2} \%$, although correlation was weaker $(r=0.11)$. These results suggest that glyoxylic acid is oxidized to oxalic acid in the course of photochemical aging that is expressed as $\mathrm{C}_{2} \%$. Similar trend was obtained for glyoxal / oxalic acid ratios (Fig. 11f). Although the sources of aerosols and source regions of air masses are significantly variable during the campaign as discussed above, these relations demonstrate that the production of oxalic acid (end product) is closely linked with the photochemical behaviors of its precursor compounds (e.g., pyruvic acid, glyoxal, methylglyoxal) and intermediate (glyoxylic acid) that have similar chemical structures as described below.

Precursors (e.g., $\left.\mathrm{CH}_{3} \mathrm{COCOOH}, \mathrm{HCO}-\mathrm{CHO}, \mathrm{CH}_{3} \mathrm{COCHO}\right) \rightarrow$ intermediate $(\mathrm{HCO}-\mathrm{COOH}) \rightarrow$ end product $(\mathrm{HOOC}-\mathrm{COOH})$

To better understand the reaction mechanisms of the precursor compounds, we examined the correlation plots for pyruvic acid $/ \mathrm{C}_{2}$ vs. $\mathrm{C}_{2} \%$ and methylglyoxal $/ \mathrm{C}_{2}$ vs. $\mathrm{C}_{2} \%$. The former plots did not show any correlation, whereas the latter plots showed a weak positive correlation $(r=0.20)$. The latter result may suggest that methylglyoxal is more produced during the enhanced photochemical aging of organic aerosols. In contrast, glyoxal $/ \mathrm{C}_{2}$ rather showed a negative correlation with $\mathrm{C}_{2} \%$, although correlation is very weak $(r=0.10)$. Further studies are needed to explore the formation mechanisms from precursors and intermediates to oxalic acid in the atmosphere.

Recently, a depletion of oxalic acid has been reported in the Arctic aerosols after polar sunrise (Kawamura et al., 2010) and the Arctic Ocean aerosols collected in summer (Kawamura et al., 2012). Although $\mathrm{C}_{2}$ is generally the most abundant diacid in the atmospheric aerosols, $\mathrm{C}_{2}$ became less abundant than $\mathrm{C}_{3}$ and $\mathrm{C}_{4}$ diacids during the $\mathrm{C}_{2}$-depletion events under the solar radiation in the presence of trace metals such as Fe (Pavuluri and Kawamura, 2012). However, in the Mt. Tai aerosols, we did not observe the depletion of oxalic acid; $\mathrm{C}_{2}$ is always the most abundant diacid, accounting for $50-85 \%$ of total $\mathrm{C}_{2}-\mathrm{C}_{10}$ diacids. So far, depletion of oxalic acid has been observed in the Arctic and Antarctic regions (Kawamura et al., 1996b, 2010, 2012), but not in the low and midlatitudes. Because Mt. Tai is surrounded by pollution sources in low lands and contributed by fresh aerosols transported by upwind, photochemical processing may not be significant enough to decompose oxalic acid compared to atmospheric aerosols from the polar regions, where halogen chemistry may be important (Barrie et al., 1988).

\section{Summary and conclusions}

Aerosol samples collected at the summit $(1534 \mathrm{~m}$ a.s.l.) of Mount Tai in central East China $\left(36.25^{\circ} \mathrm{N} ; 117.10^{\circ} \mathrm{E}\right)$ showed high loadings of dicarboxylic acids, ketocarboxylic acids and $\alpha$-dicarbonyls, whose concentrations are several times higher than those reported in Chinese megacities. Their concentrations are largely influenced by the field burning of agricultural wastes in the North China Plain and the air mass trajectories that transport the biomass burning products over the mountaintop as well as photochemical processes during the atmospheric transport. We found that total dicarboxylic acids accounted for 1.2 to $6.5 \%$ of TC and 5 to $40 \%$ of WSOC.

Although atmospheric photochemical processing over Mt. Tai is not as strong as remote marine aerosols, we detected a close link between the oxidation of glyoxylic acid and $\alpha$-dicarbonyls and production of oxalic acid. Based on the detailed analyses of molecular compositions of the organic species and the aging factor presented by the relative abundance of $\mathrm{C}_{2}$ in total diacids $\left(\mathrm{C}_{2} \%\right)$, we conclude that chain reactions in the oxidation of glyoxylic acid and methylglyoxal result in oxalic acid occurring in the aerosol aqueous phase in the atmosphere over the mountaintop. Further, this study supports that the breakdown of longer-chain diacids such as succinic acid to oxalic acid occurs in the mountaintop aerosols.

This study demonstrated that the intensive field burning of agriculture residues in early summer often enhanced watersoluble organic acids in the mountain aerosols in the free troposphere over the northern China Plain. The field burning of agricultural wastes in this region not only controls the high loading of organic aerosols in central East China but also affects the air quality and atmospheric chemistry in the outflow regions of Chinese aerosols in the western North Pacific.

Acknowledgements. This study was in part supported by the Japanese Ministry of Education, Culture, Sports, Science and Technology (MEXT) through grant-in-aid Nos. 17340166 and 19204055. We also acknowledge the financial support by the Global Environment Research Fund (B-051) of the Ministry of the Environment, Japan, for the shipping of the instruments to Mt. Tai.

L. Molina

\section{References}

Aggarwal, S. G. and Kawamura, K.: Molecular distributions and stable carbon isotopic compositions of dicarboxylic acids and related compounds in aerosols from Sapporo, Japan: Implications for photochemical aging during long-range atmospheric transport, J. Geophys. Res.-Atmos., 113, D14301, doi:10.1029/2007jd009365, 2008.

Barrie, L. A., Bottenheim, J. W., Schnell, R. C., Crutzen, P. J., and Rasmussen, R. A.: Ozone destruction and photochemical reac- 
tions at polar sunrise in the lower Arctic atmosphere, Nature, 334, 138-141, 1988.

Brooks, S. D., Wise, M. E., Cushing, M., and Tolbert, M. A.: Diliquescence behavior of organic/ammonium sulfate aerosol, Geophys. Res. Lett., 29, 1917, doi:10.1029/2002GL014733, 2002.

Carlton, A. G., Turpin, B. J., Altieri, K. E., Seitzinger, S., Reff, A., Lim, H. J., and Ervens, B.: Atmospheric oxalic acid and SOA production from glyoxal: Results of aqueous photooxidation experiments, Atmos. Environ., 41, 7588-7602, 2007.

Charbouillot, T., Gorini, S., Voyard, G., Parazols, M., Brigante, M., Deguillaume, L., Delort, A. M., and Mailhot, G.: Mechanism of carboxylic acid photooxidation in atmospheric aqueous phase: Formation, fate and reactivity, Atmos. Environ., 56, 1-8, 2012.

Cooke, W. F., Liousse, C., Cachier, H., and Feichter, J.: Construction of a 1 degrees $\times 1$ degrees fossil fuel emission data set for carbonaceous aerosol and implementation and radiative impact in the ECHAM4 model, J. Geophys. Res., Atmos., 104, 2213722162, 1999.

Cruz, C. N. and Pandis, S. N.: The effect of organic coatings on the cloud condensation nuclei activation of inorganic atmospheric aerosol, J. Geophys. Res. Atmos., 103, 13111-13123, 1998.

Engling, G., Carrico, C. M., Kreldenweis, S. M., Collett, J. L., Day, D. E., Malm, W. C., Lincoln, E., Hao, W. M., Iinuma, Y., and Herrmann, H.: Determination of levoglucosan in biomass combustion aerosol by high-performance anion-exchange chromatography with pulsed amperometric detection, Atmos. Environ., 40, S299-S311, 2006.

Ervens, B., Carlton, A. G., Turpin, B. J., Altieri, K. E., Kreidenweis, S. M., and Feingold, G.: Secondary organic aerosol yields from cloud-processing of isoprene oxidation products, Geophys. Res. Lett., 35, L02816, doi:10.1029/2007GL031828, 2008.

Ervens, B., Turpin, B. J., and Weber, R. J.: Secondary organic aerosol formation in cloud droplets and aqueous particles (aqSOA): a review of laboratory, field and model studies, Atmos. Chem. Phys., 11, 11069-11102, doi:10.5194/acp-1111069-2011, 2011.

Fu, P., Kawamura, K., Usukura, K., and Miura, K.: Dicarboxylic acids, ketocarboxylic acids and glyoxal in the marine aerosols collected during a round-the-world cruise, Mar. Chem., 148, 2232, 2013.

Fu, P. Q., Kawamura, K., Okuzawa, K., Aggarwal, S. G., Wang, G., Kanaya, Y. and Wang, Z.: Organic molecular compositions and temporal variations of summertime mountain aerosols over Mt. Tai, North China Plain, J. Geophys. Res. Atmos., 113, D19107, doi:10.1029/2008JD009900, 2008.

Gao, J., Wang, T., Ding, A. J., and Liu, C. B.: Observational study of ozone and carbon monoxide at the summit of mount Tai (1534 $\mathrm{m}$ a.s.1.) in central-eastern China, Atmos. Environ., 39, 4779-4791, 2005.

Hatakeyama, S., Tanonaka, T., Weng, J. H., Bandow, H., Takagi, H. and Akimoto, H.: Ozone cyclohexene reaction in air - quantitative-analysis of particulate products and the reactionmechanism, Environ. Sci. Technol., 19, 935-942, 1985.

Hayashida, S., Urita, N., Noguchi, K., Liu, X., and Chance, K.: Spatiotemporal Variation in Tropospheric Column Ozone over East Asia Observed by GOME and Ozonesondes, Sola, 4, 117-120, 2008.
He, N. and Kawamura, K.: Distributions and diurnal changes of low molecular weight organic acids and alpha-dicarbonyls in suburban aerosols collected at Mangshan, North China, Geochem. J., 44, E17-E22, 2010.

Hegde, P. and Kawamura, K.: Seasonal variations of water-soluble organic carbon, dicarboxylic acids, ketocarboxylic acids, and $\alpha$ dicarbonyls in Central Himalayan aerosols, Atmos. Chem. Phys., 12, 6645-6665, doi:10.5194/acp-12-6645-2012, 2012.

Ho, K. F., Cao, J. J., Lee, S. C., Kawamura, K., Zhang, R. J., Chow, J. C. and Watson, J. G.: Dicarboxylic acids, ketocarboxylic acids, and dicarbonyls in the urban atmosphere of China, J. Geophys. Res.-Atmos., 112, D22s27, doi:10.1029/2006jd008011, 2007.

Ho, K. F., Lee, S. C., Ho, S. S. H., Kawamura, K., Tachibana, E., Cheng, Y., and Zhu, T.: Dicarboxylic acids, ketocarboxylic acids, alpha-dicarbonyls, fatty acids, and benzoic acid in urban aerosols collected during the 2006 Campaign of Air Quality Research in Beijing (CAREBeijing-2006), J. Geophys. Res.-Atmos., 115, D19312, doi:10.1029/2009jd013304, 2010.

Ho, K. F., Ho, S. S. H., Lee, S. C., Kawamura, K., Zou, S. C., Cao, J. J., and $\mathrm{Xu}, \mathrm{H}$. M.: Summer and winter variations of dicarboxylic acids, fatty acids and benzoic acid in $\mathrm{PM}_{2.5}$ in Pearl Delta River Region, China, Atmos. Chem. Phys., 11, 2197-2208, doi:10.5194/acp-11-2197-2011, 2011.

Huebert, B. J., Bates, T., Russell, P. B., Shi, G. Y., Kim, Y. J., Kawamura, K., Carmichael, G., and Nakajima, T.: An overview of ACE-Asia: Strategies for quantifying the relationships between Asian aerosols and their climatic impacts, J. Geophys. Res. Atmos, 108, 8633, doi:10.1029/2003JD003550, 2003.

Kanaya, Y., Akimoto, H., Wang, Z.-F., Pochanart, P., Kawamura, K., Liu, Y., Li, J., Komazaki, Y., Irie, H., Pan, X.-L., Taketani, F., Yamaji, K., Tanimoto, H., Inomata, S., Kato, S., Suthawaree, J., Okuzawa, K., Wang, G., Aggarwal, S. G., Fu, P. Q., Wang, T., Gao, J., Wang, Y., and Zhuang, G.: Overview of the Mount Tai Experiment (MTX2006) in central East China in June 2006: studies of significant regional air pollution, Atmos. Chem. Phys., 13, 8265-8283, doi:10.5194/acp-13-8265-2013, 2013.

Kawamura, K.: Identification of $\mathrm{C} 2-\mathrm{C} 10 \omega$-oxocarboxylic acids, pyruvic acid, and C2-C3 $\alpha$-dicarbonyls in wet precipitation and aerosol samples by capillary GC and GC/MS, Anal. Chem., 65, 3505-3511, 1993.

Kawamura, K. and Gagosian, R. B.: Implications of $\omega$ oxocarboxylic acids in the remote marine atmosphere for photooxidation of unsaturated fatty acids, Nature, 325, 330-332, 1987.

Kawamura, K. and Ikushima, K.: Seasonal changes in the distribution of dicarboxylic acids in the urban atmosphere, Environ. Sci. Technol., 27, 2227-2235, 1993.

Kawamura, K. and Kaplan, I. R.: Motor exhaust emissions as a primary source for dicarboxylic acids in Los Angels ambient air, Environ. Sci. Technol., 21, 105-110, 1987.

Kawamura, K. and Sakaguchi, F.: Molecular distributions of water soluble dicarboxylic acids in marine aerosols over the Pacific Ocean including tropics, J. Geophys. Res. Atmos., 104, 35013509, 1999.

Kawamura, K. and Yasui, O.: Diurnal changes in the distribution of dicarboxylic acids, ketocarboxylic acids and dicarbonyls in the urban Tokyo atmosphere, Atmos. Environ., 39, 1945-1960, 2005.

Kawamura, K., Steinberg, S. and Kaplan, I. R.: Capillary GC determination of short-chain dicarboxylic-acids in rain, fog, and mist, 
Int. J. Environ. Anal. Chem., 19, 175-188, 1985.

Kawamura, K., Kasukabe, H., and Barrie, L. A.: Source and reaction pathways of dicarboxylic acids, ketoacids and dicarbonyls in arctic aerosols: One year of observations, Atmos. Environ., 30, 1709-1722, 1996a.

Kawamura, K., Sempéré, R., Imai, Y., Fujii, Y. and Hayashi, M.: Water soluble dicarboxylic acids and related compounds in Antarctic aerosols, J. Geophys. Res.-Atmos., 101, 18721-18728, 1996b.

Kawamura, K., Kobayashi, M., Tsubonuma, N., Mochida, M., Watanabe, T., and Lee, M.: Organic and inorganic compositions of marine aerosols from East Asia: Seasonal variations of watersoluble dicarboxylic acids, major ions, total carbon and nitrogen, and stable $\mathrm{C}$ and $\mathrm{N}$ isotopic composition. In: R.J. Hill, J. Leventhal, Z. Aizenshtat, M.J. Baedecker, G. Claypool, R. Eganhouse, M. Goldhaber and K. Peters, Editors, Geochemical Investigations in Earth and Space Science: A Tribute to Isaac R. Kaplan, Geochem. Soc., 243-265, 2004.

Kawamura, K., Imai, Y., and Barrie, L. A.: Photochemical production and loss of organic acids in high Arctic aerosols during longrange transport and polar sunrise ozone depletion events, Atmos. Environ., 39, 599-614, 2005.

Kawamura, K., Kasukabe, H., and Barrie, L. A.: Secondary formation of water-soluble organic acids and $\alpha$-dicarbonyls and their contributions to total carbon and water-soluble organic carbon: Photochemical aging of organic aerosols in the Arctic spring, J. Geophys. Res.-Atmos., 115, D21306, doi:10.1029/2010jd014299, 2010.

Kawamura, K., Ono, K., Tachibana, E., Charriére, B., and Sempéré, R.: Distributions of low molecular weight dicarboxylic acids, ketoacids and $\alpha$-dicarbonyls in the marine aerosols collected over the Arctic Ocean during late summer, Biogeosciences, 9, 47254737, doi:10.5194/bg-9-4725-2012, 2012.

Kawamura, K., Okuzawa, K., Aggarwal, S. G., Irie, H., Kanaya, Y., and Wang, Z.: Determination of gaseous and particulate carbonyls (glycolaldehyde, hydroxyacetone, glyoxal, methylglyoxal, nonanal and decanal) in the atmosphere at Mt. Tai, Atmos. Chem. Phys., 13, 5369-5380, doi:10.5194/acp-13-53692013, 2013.

Kerminen, V. M., Teinila, K., Hillamo, R., and Makela, T.: Sizesegregated chemistry of particulate dicarboxylic acids in the Arctic atmosphere, Atmos. Environ., 33, 2089-2100, 1999.

Kitanovski, Z., Grgic, I., and Veber, M.: Characterization of carboxylic acids in atmospheric aerosols using hydrophilic interaction liquid chromatography tandem mass spectrometry, J. Chromatogr. A, 1218, 4417-4425, 2011.

Kundu, S., Kawamura, K., Andreae, T. W., Hoffer, A., and Andreae, M. O.: Molecular distributions of dicarboxylic acids, ketocarboxylic acids and $\alpha$-dicarbonyls in biomass burning aerosols: implications for photochemical production and degradation in smoke layers, Atmos. Chem. Phys., 10, 2209-2225, doi:10.5194/acp-10-2209-2010, 2010a.

Kundu, S., Kawamura, K., and Lee, M.: Seasonal variations of diacids, ketoacids, and $\alpha$-dicarbonyls in aerosols at Gosan, Jeju Island, South Korea: Implications for sources, formation, and degradation during long-range transport, J. Geophys. Res.Atmos., 115, D19307, doi:10.1029/2010jd013973, 2010b.

Legrand, M. and de Angelis, M.: Light carboxylic acids in Greenland ice: A record of past forest fires and vegetation emissions from the boreal zone, J. Geophys. Res.-Atmos., 101, 412-4145, 1996.

Legrand, M., Preunkert, S., Oliveira, T., Pio, C. A., Hammer, S., Gelencser, A., Kasper-Giebl, A. and Laj, P.: Origin of C2-C5 dicarboxylic acids in the European atmosphere inferred from yearround aerosol study conducted at a west-east transect, J. Geophys. Res.-Atmos., 112, D23S07, doi:10.1029/2006jd008019, 2007.

Li, J., Wang, Z., Akimoto, H., Yamaji, K., Takigawa, M., Pochanart, P., Liu, Y., Tanimoto, H., and Kanaya, Y.: Nearground ozone source attributions and outflow in central eastern China during MTX2006, Atmos. Chem. Phys., 8, 7335-7351, doi:10.5194/acp-8-7335-2008, 2008.

Lim, H. J., Carlton, A. G., and Turpin, B. J.: Isoprene forms secondary organic aerosol through cloud processing: Model simulations, Environ. Sci. Technol., 39, 4441-4446, 2005.

Miyazaki, Y., Aggarwal, S. G., Singh, K., Gupta, P. K., and Kawamura, K.: Dicarboxylic acids and water-soluble organic carbon in aerosols in New Delhi, India, in winter: Characteristics and formation processes, J. Geophys. Res. Atmos., 114, D19206, doi:10.1029/2009jd011790, 2009.

Miyazaki, Y., Kawamura, K., and Sawano, M.: Size distributions and chemical characterization of water-soluble organic aerosols over the western North Pacific in summer, J. Geophys. Res.Atmos., 115, D23210, doi:10.1029/2010jd014439, 2010.

Miyazaki, Y., Kawamura, K., Jung, J., Furutani, H., and Uematsu, M.: Latitudinal distributions of organic nitrogen and organic carbon in marine aerosols over the western North Pacific, Atmos. Chem. Phys., 11, 3037-3049, doi:10.5194/acp-11-3037-2011, 2011.

Mochida, M., Kawabata, A., Kawamura, K., Hatsushika, H. and Yamazaki, K.: Seasonal variation and origins of dicarboxylic acids in the marine atmosphere over the western North Pacific, J. Geophys. Res. Atmos., 108, 4193, doi:10.1029/2002JD002355, 2003a.

Mochida, M., Kawamura, K., Umemoto, N., Kobayashi, M., Matsunaga, S., Lim, H. J., Turpin, B. J., Bates, T. S., and Simoneit, B. R. T.: Spatial distributions of oxygenated organic compounds (dicarboxylic acids, fatty acids, and levoglucosan) in marine aerosols over the western Pacific and off the coast of East Asia: Continental outflow of organic aerosols during the ACE-Asia campaign, J. Geophys. Res. Atmos., 108, 8638, doi:10.1029/2002JD003249, 2003b.

Narukawa, M., Kawamura, K., Takeuchi, N., and Nakajima, T.: Distribution of dicarboxylic acids and carbon isotopic compositions in aerosols from 1997 Indonesian forest fires, Geophys Res. Lett., 26, 3101-3104, 1999.

Narukawa, M., Kawamura, K., Li, S. M., and Bottenheim, J. W.: Dicarboxylic acids in the Arctic aerosols and snowpacks collected during ALERT 2000, Atmos. Environ., 36, 2491-2499, 2002.

Narukawa, M., Kawamura, K., Anlauf, K. G., and Barrie, L. A.: Fine and coarse modes of dicarboxylic acids in the Arctic aerosols collected during the Polar Sunrise Experiment 1997, J. Geophys. Res. Atmos., 108, 4575, doi:10.1029/2003JD003646 2003.

Ohara, T., Akimoto, H., Kurokawa, J., Horii, N., Yamaji, K., Yan, X., and Hayasaka, T.: An Asian emission inventory of anthropogenic emission sources for the period 1980-2020, Atmos. Chem. Phys., 7, 4419-4444, doi:10.5194/acp-7-4419-2007, 
2007.

Pavuluri, C. M. and Kawamura, K.: Evidence for 13-carbon enrichment in oxalic acid via iron catalyzed photolysis in aqueous phase, Geophys. Res. Lett., 39, L03802, doi:10.1029/2011GL050398, 2012.

Richter, A., Burrows, J. P., Nuss, H., Granier, C., and Niemeier, U.: Increase in tropospheric nitrogen dioxide over China observed from space, Nature, 437, 129-132, 2005.

Rinaldi, M., Decesari, S., Carbone, C., Finessi, E., Fuzzi, S., Ceburnis, D., O'Dowd, C. D., Sciare, J., Burrows, J. P., Vrekoussis, M., Ervens, B., Tsigaridis, K. and Facchini, M. C.: Evidence of a natural marine source of oxalic acid and a possible link to glyoxal, J. Geophys. Res. Atmos., 116, D16204, doi:10.1029/2011JD015659, 2011.

Rohrl, A. and Lammel, G.: Low molecular weight dicarboxylic acids and glyoxylic acid: Seasonal and air mass characteristics, Environ. Sci. Technol., 35, 95-101, 2001.

Rompp, A., Winterhalter, R., and Moortgat, G. K.: Oxodicarboxylic acids in atmospheric aerosol particles, Atmos. Environ., 40, 6846-6862, 2006.

Saxena, P. and Hildemann, L. M.: Water-soluble organics in atmospheric particles: A critical review of the literature and application of thermodynamics to identify candidate compounds, J. Atmos. Chem., 24, 57-109, 1996.

Saxena, P., Hildemann, L. M., McMurry, P. H., and Seinfeld, J. H.: Organics alter hydroscopic bahavior of atmospheric particles, J. Geophys. Res., 100, 18755-18770, 1995.

Schauer, J. J., Kleeman, M. J., Cass, G. R. and Simoneit, B. R. T.: Measurement of emission from air pollution sources. 4. $C_{1}-C_{27}$ organic compounds from cooking with seed oils, Environ. Sci. Technol., 36, 567-575, 2002.

Sempéré, R., and Kawamura, K.: Comparative distributions of dicarboxylic-acids and related polar compounds in snow rain and aerosols from urban atmosphere, Atmos. Environ., 28, 449-459, 1994.

Simoneit, B. R. T.: Biomass burning-a review of organic tracers for smoke from incomplete combustion, Appl. Geochem., 17, 129_ $162,2002$.

Simoneit, B. R. T., Schauer, J. J., Nolte, C. G., Oros, D. R., Elias, V. O., Fraser, M. P., Rogge, W. F., and Cass, G. R.: Levoglucosan, a tracer for cellulose in biomass burning and atmospheric particles, Atmos. Environ., 33, 173-182, 1999.

Sorooshian, A., Varutbangkul, V., Brechtel, F. J., Ervens, B., Feingold, G., Bahreini, R., Murphy, S. M., Holloway, J. S., Atlas, E. L., Buzorius, G., Jonsson, H., Flagan, R. C., and Seinfeld, J. H.: Oxalic acid in clear and cloudy atmospheres: Analysis of data from International Consortium for Atmospheric Research on Transport and Transformation 2004, J. Geophys. Res.-Atmos., 111, D23S45, doi:10.1029/2005JD006880, 2006.
Stephanou, E. G.: $\alpha, \omega$-Dicarboxylic acid salts and $\alpha, \omega$ dicarboxylic acids - photooxidation products of unsaturated fatty acids present in marine aerosols and marine sediments, Naturwissenschaften, 79, 128-131, 1992.

Streets, D. G., Bond, T. C., Lee, T., and Jang, C.: On the future of carbonaceous aerosol emissions, J. Geophys. Res. Atmos., 109, D24212, doi:10.21029/22004JD004902, 2004.

Wang, G. and Kawamura, K.: Molecular characteristics of urban organic aerosols from Nanjing: A case study of a mega-city in China, Environ. Sci. Technol., 39, 7430-7438, 2005.

Wang, G., Niu, S., Liu, C., and Wang, L.: Identification of dicarboxylic acids and aldehyde of $\mathrm{PM}_{10}$ and $\mathrm{PM}_{2.5}$ aerosols in Nanjing, China, Atmos. Environ., 36, 1941-1950, 2002.

Wang, G., Kawamura, K., Lee, S., Ho, K. F. and Cao, J. J.: Molecular, seasonal, and spatial distributions of organic aerosols from fourteen Chinese cities, Environ. Sci. Technol., 40, 4619-4625, 2006 a.

Wang, G. H., Kawamura, K., Xie, M. J., Hu, S. Y., Cao, J. J., An, Z. S., Waston, J. G. and Chow, J. C.: Organic Molecular Compositions and Size Distributions of Chinese Summer and Autumn Aerosols from Nanjing: Characteristic Haze Event Caused by Wheat Straw Burning, Environ. Sci. Technol., 43, 6493-6499, 2009.

Wang, G. H., Kawamura, K., Cheng, C. L., Li, J. J., Cao, J. J., Zhang, R. J., Zhang, T., Liu, S. X. and Zhao, Z. Z.: Molecular Distribution and Stable Carbon Isotopic Composition of Dicarboxylic Acids, Ketocarboxylic Acids, and alpha-Dicarbonyls in Size-Resolved Atmospheric Particles From Xi' an City, China, Environ. Sci. Technol., 46, 4783-4791, 2012.

Wang, H. B., Kawamura, K. and Yamazaki, K.: Water-soluble dicarboxylic acids, ketoacids and dicarbonyls in the atmospheric aerosols over the Southern Ocean and western Pacific Ocean, J. Atmos. Chem., 53, 43-61, 2006b.

Warneck, P.: In-cloud chemistry opens pathway to the formation of oxalic acid in the marine atmosphere, Atmos. Environ., 37, 2423-2427, 2003.

Yao, X. H., Fang, M., and Chan, C. K.: Size distributions and formation of dicarboxylic acids in atmospheric particles, Atmos. Environ., 36, 2099-2107, 2002.

Yokouchi, Y. and Ambe, Y.: Characterization of Polar Organics in Airborne Particulate Matter, Atmos. Environ., 20, 1727-1734, 1986. 